\title{
Policy and Performance Links between LDC Debtors and Industrial Nations
}

IN 1984 spokesmen for heavily indebted developing nations complained about the sharp interest rate increases that had come in the wake of the U.S. economic recovery. Emphasizing that the U.S. recovery had also spilled over into record export growth rates for developing countries, President Reagan commented on the trade-offs in the following terms:

We sometimes hear complaints about U.S. interest rates, particularly by debtor nations, which are legitimately concerned about the additional debt service costs they must bear. But not enough mention is made of trade and the far greater benefits developing countries receive from renewed economic growth and open market policies of the United States.

For the U.S. alone, imports from the non-Opec LDC's during the first seven months of this year increased by more than $\$ 12$ billion over the amount during the same period last year. By comparison, a 1 percent increase in interest rates would increase net interest payments by the non-Opec LDC's by only $\$ 2.5$ billion. ${ }^{1}$

This paper investigates the impact of macroeconomic developments in the industrialized nations on LDCs, in part to assess such trade-offs as that between increased LDC exports and higher interest rates resulting from U.S. growth. Such assessments will help in understanding the sharply divergent economic performance of LDCs and in judging whether the current debt crisis can be expected to disappear through the

I am indebted to members of the Brookings Panel for helpful comments and suggestions. David Wilcox provided research assistance. Data Resources, Inc., generously made available computing facilities.

1. Reported in the New York Times, September 26, 1984, p. D5. 
mere passage of time or only through major and painful adjustments on the part of LDCs, for which some may be better equipped or positioned than others.

A starting point is a comparison of recent growth performance among LDCs in Asia and in Latin America. Shown below are growth rates in real income per capita for the period 1980-84 (1980-83 in the case of Indonesia) for several countries.

\section{Annual rate of growth (percent)}

Asia

Indonesia

Korea

Malaysia

Thailand

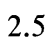

5.9

4.2

3.6
Latin America

$\begin{array}{ll}\text { Argentina } & -3.2 \\ \text { Brazil } & -2.4 \\ \text { Chile } & -2.9 \\ \text { Mexico } & -1.0\end{array}$

The striking difference in performance among the LDCs raises the question of what role external factors have played directly or indirectly. There are three basic, possibly complementary, hypotheses. The first is that individual LDCs have simply been affected in different ways by developments in the world economy. But that is only possible to the extent that the LDCs differ in their trade structure or in their initial conditions, especially in respect to indebtedness. The second hypothesis emphasizes differences in domestic policies, some countries having pursued trade-oriented policies and moderation in budget deficits while others promoted waste and inefficiency. The third hypothesis emphasizes a differential ability to adapt to external shocks or take advantage of opportunities posed by the world market.

As shown in table 1, the external environment facing the LDCs can differ radically over time. LDCs may face high interest rates, low inflation, and weak growth, as in 1980-82, or they may experience debt liquidation from high inflation and a world boom, as in 1970-73, or they may face a mix such as that prevailing in 1983-84. Furthermore, the scenarios may differ in that the U.S. dollar may be weak or strong in world markets. The question then becomes how to evaluate the impact of the different combinations of inflation, interest rates, and OECD growth on a particular LDC.

Obviously, it will not be enough to know that OECD growth is, say, 3 percent to infer the impact of the industrialized economies on a particular LDC. Various combinations of OECD policy mixes and LDC 
Table 1. Key Macroeconomic Variables of the World Economy, 1970-84a

Average annual percentage rates

\begin{tabular}{ccccc}
\hline & & \multicolumn{3}{c}{ Inflation } \\
\cline { 3 - 4 } Period & LIBOR & Manufactures & Commodities & OECD growth \\
\hline $1970-73$ & 7.6 & 12.4 & 14.4 & 5.9 \\
$1980-82$ & 14.7 & -2.4 & -13.3 & 0.9 \\
$1983-84$ & 10.3 & -1.8 & 5.2 & 3.8 \\
\hline
\end{tabular}

Sources: International Monetary Fund, International Financial Statistics, and Data Resources, Inc.

a. LIBOR is the London interbank offer rate for deposits. The inflation rate is measured for manufactures by the export unit value of exports from industrialized countries and for commodities by the IMF index for all commodities, excluding oil.

trade and debt structures can have different interest rate-exchange rate implications that give rise to a number of different outcomes depending on whether the country is heavily indebted to banks and whether it is a net exporter or importer of commodities.

A simple model of a semi-small open economy illustrates these points, identifying the channels of external influences and specifying the way in which they affect economic performance. The essential point of the model is to introduce a sharp distinction between welfare-based assessments of the linkages between OECD countries and LDCs and the cashflow models that are current in the discussion of debt problems. Of course, any country is open and thus is affected by external shocks, a point that is discussed in the second section, on economic structure. The third section quantifies external influences. The fourth deals with policy issues, concentrating especially on the economic and political sustainability of debts. The final section concludes that the involuntary debt service that is under way is too costly in economic and political terms to continue on its course, without either rationale or target.

\section{A Framework}

The model set out in this section describes the external influences on LDC macroeconomic variables and welfare. It emphasizes the role of relative prices, which do not receive prominence in the closed-economy U.S. macroeconomic tradition, but which, as is shown below, are important in a welfare-theoretic framework.

In the model, the LDC, the home country, produces three goods: home, or nontraded goods, which can be thought of as services; export- 
ables, or manufactures; and primary commodities, or materials. ${ }^{2}$ Domestic spending falls on all three of these goods and, in addition, on imported manufactures. The world price of commodities, $P_{c}$, and of imported manufactures, $P_{m}^{*}$, is given. I denote by $p^{*}=P_{c} / P_{m}^{*}$ the world relative, or real, price of commodities in terms of manufactures, which the individual LDC takes as given. Aside from the levels, or paths, of these prices, the country also takes as given the nominal world interest rate on loans, $i^{*}$.

The prices of domestic manufactures and of nontraded goods are $P_{m}$ and $P_{n}$, respectively. The world manufactures price is used as a numeraire to define the relative, or real, prices of domestic manufactures and nontraded goods as $p_{m}=P_{m} / P_{m}^{*}$ and $p_{n}=P_{n} / P_{m}^{*}$, respectively. With given factor supplies and wage-price flexibility assumed, the supply functions of the three goods (manufactures, commodities, and nontraded goods) are obtained as functions of the three relative prices.

Equilibrium in the market for manufactures requires that supply equal domestic plus foreign demand. In the nontraded goods market, equilibrium requires the equality of home demand and supply:

$$
\begin{aligned}
Q_{m}\left(p_{m}, p_{n}, p^{*}\right) & =D_{m}\left(p_{m}, p_{n}, p^{*}, y, i^{*}\right)+D_{m}{ }^{*}\left(p_{m}, y^{*}, i^{*}\right), \\
Q_{n}\left(p_{m}, p_{n}, p^{*}\right) & =D_{n}\left(p_{m}, p_{n}, p^{*}, y, i^{*}\right),
\end{aligned}
$$

where $y$ denotes real income.

In figure 1 the market equilibrium schedules are labeled, respectively, $M M$ and $N N$ on the assumption of gross substitution. They are drawn for given external variables $p^{*}, i^{*}$, and $y^{*}$. Along $M M$ the market for domestic manufactures clears. An increase in the price of domestic manufactures relative to the price of those produced abroad creates an excess supply. To clear the market the real price of nontraded goods must rise, inducing substitution toward manufactures. A similar argument establishes the slope of the $N N$ schedule. Point $E$ is the fullemployment equilibrium where the markets for nontraded goods and for home manufactures clear. There is no need to look for equilibrium in the market for commodities, since these face a given price and perfectly elastic demand in world markets. Nor is there a need to worry about

2. Throughout I use interchangeably the terms commodities, primary commodities, and materials to designate goods that obey, by virtue of not being differentiated, the law of one price. For concreteness the reader might think of copper. 
Figure 1. Equilibrium Relative Prices

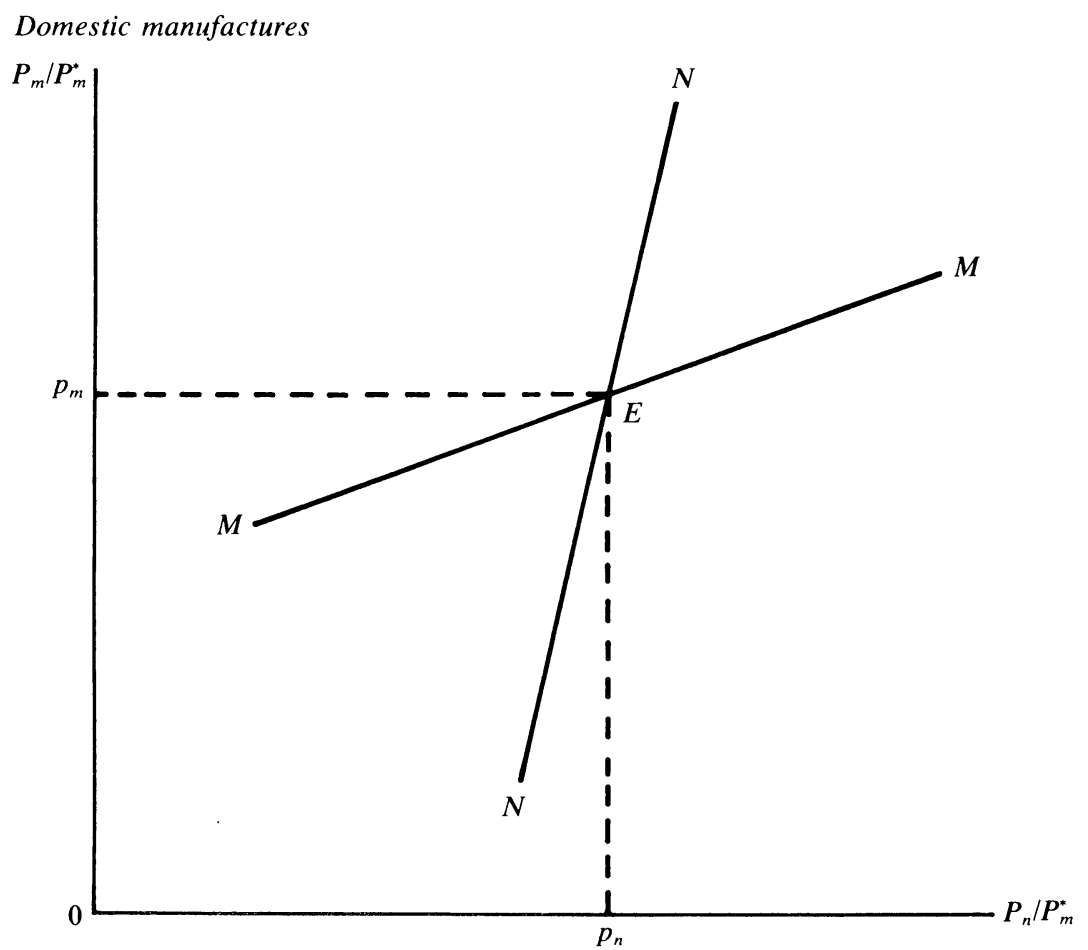

Nontraded goods

external balance, since the ability to borrow at a given world interest rate means that any current account imbalance can be financed. Budget constraints are respected, since the behavioral equations are derived by maximization subject to these constraints.

The equilibrium at point $E$ depends on a number of parameters. Specifically, the foreign parameters are the world real price of commodities, $p^{*}$, the level of world income or activity, $y^{*}$, and the world rate of interest, $i^{*}$. Equilibrium also depends on the real value of the external debt, since a large real external debt reduces real disposable income. A useful special case of the model is the "small country" variant, which arises when substitutability between home and foreign manufactures is perfect. In that case, $M M$ in figure 1 is flat because demand for home manufactures is perfectly elastic. The special case is an interesting one 
because demand factors play no role and at least one foreign determinant of domestic welfare becomes inoperative. ${ }^{3}$

The next question is how changes in these variables affect the LDC in the model. Consider first a fall in the world real price of commodities. For a producer of commodities, lower real prices lower factor costs and increase supplies of both manufactures and services. But the chief effect works on the demand side, where the reduction in real income from the worsening in the terms of trade reduces income and spending, including spending on domestic manufactures and nontraded goods. Figure 2 shows the effect as a downward shift of both $M M$ and $N N$. The equilibrium real prices of manufactures and of services must adjust to maintain full employment. The result is a gain in external competitiveness in manufacturing as $p_{m}$ declines, and a real currency depreciation as measured by the decline in the real price of home goods, $p_{n}$.

When the LDC is only a consumer, not a producer, of commodities, the change in the world price will work primarily via the income effect on the demand side. Any effects on the production side and any substitution effects on the demand side can be assumed secondary to the income effect. When the home country is a net importer of commodities, lower real commodity prices imply improved terms of trade or increased real income. As a result, demand increases for all goods, including home manufactures and services. A fall in commodity prices therefore raises the full-employment real prices of both home manufactures and services.

A rise in world activity, for given real commodity prices, will show in the LDC only in the market for manufactures. Increased foreign income and spending now create an excess demand so that the $M M$ schedule in figure 1 shifts up and to the left. The equilibrium real price of domestic manufactures rises, and the real price of home goods increases.

The third disturbance to consider is an increase in the world interest rate, which, given the path of prices, depresses borrowing and spending in the LDC in two ways. One is the reduction in real disposable income: increased interest rates imply increased debt service and hence a

3. For a discussion of small, large, and semi-large countries and the policy implications, see William Branson, "Economic Structure and Policy for External Balance," in A. W. Hooke, ed., Exchange Rate Regimes and Policy Interdependence (International Monetary Fund, 1983), pp. 39-74, and John Williamson, The Small Country in the World Economy (Basic Books, 1983). 
Figure 2. The Effect of a Decline in Real Commodity Prices

Domestic manufactures

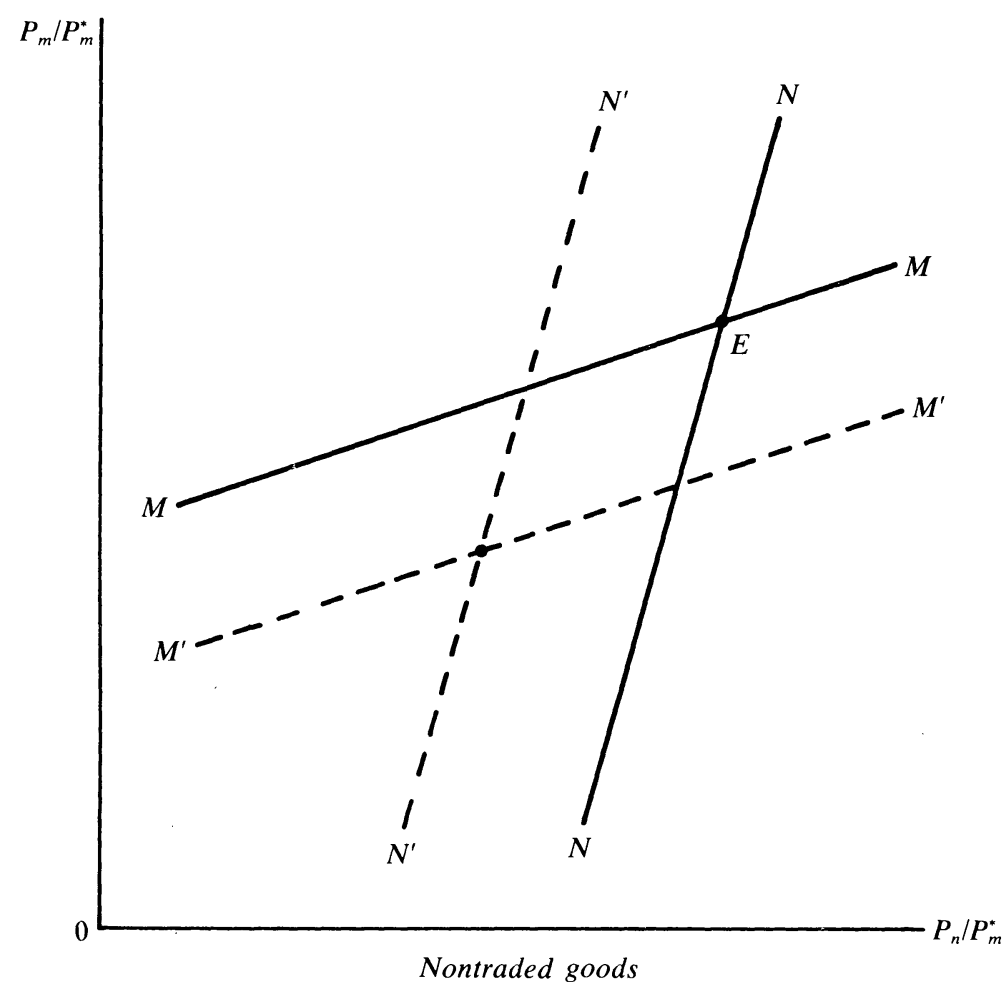

deterioration in the intertemporal terms of trade. The other is the conventional substitution effect of reduced investment and increased saving in the face of increased interest rates. With the reduction in the demand for home manufactures and nontraded goods, both the $M M$ and $N N$ schedules shift, as in figure 2 , leading to a decline in the equilibrium real prices of both.

Domestic real disposable income, $y$, is measured by GNP and thus is net of interest payments on the external debt. An increase in world interest rates therefore raises the cost of debt service on floating rate debt and reduces real disposable income. The same effect occurs from an increase in the real value of external debt due to a once-and-for-all fall in the commodity price level. Increased real debt from this source 
depresses spending and therefore reduces the equilibrium real prices of manufactures and services. In summary, the analysis identifies three principal channels of foreign influence on the LDC economy:

-the real price of primary commodities, which is determined in world markets;

- the world rate of interest on the LDC's debts; and

- the level of world demand, which affects demand for LDC manufactures exports.

I now turn to a welfare-theoretic analysis of the effects of changes in these external variables.

WELFARE ANALYSIS

The impact of external disturbances shows in the model entirely via changes in the equilibrium real prices of exportables and nontraded goods. Because of wage-price flexibility, no employment issues arise. Nor do payments problems arise, because budget constraints are not violated, and planned external imbalances can be financed in the world capital market. Nonetheless, external shocks matter for welfare. The appendix shows that in a two-period framework the welfare effects of foreign disturbances, measured in terms of current real income and denoted by the term $\Delta W$, can be summarized in the following form:

$$
\Delta W=-\Sigma\left(M_{i} \mathrm{~d} p_{i}+R^{*} M_{i}^{t+1} \mathrm{~d} p_{i}^{t+1}\right)+K\left(\frac{\mathrm{d} R^{*}}{R^{*}}\right)-\mathrm{d} b,
$$

where $M_{i}$ is import volume

$p_{i}$ is the relative price of imports in terms of exports

$R^{*}$ is the international real discount factor

$b$ is the real value of the initial debt

$K$ is the initial debt plus first period trade deficit.

The equation quantifies the impact of external disturbances on welfare. The first term shows that a terms-of-trade deterioration lowers welfare. The second term identifies the welfare costs of a change in the real discount factor. The welfare effect of the terms-of-trade deterioration is proportional to the level of imports. The welfare cost of increased real interest rates is proportional to the initial debt plus current borrowing. Note that equation 3 uses the real, not the nominal, interest rate. I 
return to this issue below in an application of the welfare change formula. The third term measures the welfare costs of increases in the initial debt via a decline in prices or the gain from write-offs.

A rise in interest rates reduces real disposable income and hence welfare. Moreover, adjustment to increased real interest rates involves a secondary burden via a deterioration in the terms of trade. As domestic demand declines in response to reduced real income, there is an excess supply of domestic goods and hence unemployment. Full employment can be sustained only if the real price of domestic manufactures declines in terms of foreign manufactures to increase competitiveness and hence world demand for domestic goods. The terms-of-trade deterioration further worsens welfare by reducing the purchasing power of a given factor income. This secondary burden, familiar from the transfer problem associated with German reparation payments in the $1920 \mathrm{~s},{ }^{4}$ must arise any time a country's factor supplies are put on sale internationally in order to sustain full employment in the face of a fall in income and spending.

How large this terms-of-trade deterioration would need to be depends on the pattern of spending reduction in response to the drop in disposable income, the substitutability of manufactures and nontraded goods at home, and the substitutability between home manufactures and those produced abroad. If the spending cut could fall entirely on foreign goods, there would be no reduction in spending on domestic goods and hence no unemployed resources. But, of course, part of the reduction in spending will fall on domestic nontraded goods and on exportables. To make up for the slack, foreign demand for domestic goods must be encouraged by a cut in the real price. The cut must be larger the less substitutability there is between home and foreign manufactures.

Exactly the same issue of a secondary burden occurs in the case of an increase in the real price of commodities in world markets. The termsof-trade deterioration of an importing country means reduced real income and hence a cut in spending. A decline in the real price of exports in terms of foreign manufactures will be required to sustain full employment, thus further adding to the welfare cost of increased import prices. In the case of a commodity exporting country, the balance goes the other way: increased commodity prices raise real income and home spending,

4. See Robert A. Mundell, International Economics (Macmillan, 1968). 
and therefore create tight factor markets and hence a further terms-oftrade improvement via increased prices of manufactures exports. In terms of figure 2, a relatively flat $M M$ schedule minimizes the secondary burden, while a relatively steep one makes it potentially important. This issue becomes particularly significant in the discussion of adjustment difficulties below.

Equation 3 shows no welfare effects of increased foreign demand. Because there are no distortions, increased foreign demand represents a benefit only to the extent that it brings about a favorable change in the equilibrium terms of trade. In the absence of distortions, international effects on home welfare are therefore fully described by the income effect associated with price or interest rate changes. There is nothing else: all international influences are the transfers implicit in interest rate and terms-of-trade changes. Of course, these interest rate or terms-oftrade changes in turn will have as their source foreign disturbances such as monetary or fiscal policy changes.

Equation 3 makes the further point that the income effects are proportional to a country's exposure. Higher interest rates reduce welfare in proportion to indebtedness. A terms-of-trade deterioration reduces welfare in proportion to imports. This is one place where structural differences between countries come into play.

\section{AN APPLICATION}

It is possible now to return to President Reagan's remarks to judge whether in fact, in welfare terms, there is a one-for-one trade-off between extra debt service and extra export revenue. Clearly, in terms of the present analysis, that is not the case. There is such a trade-off between terms-of-trade improvements and extra interest, as shown in equation 3 , but not in terms of export revenue. Changes in export revenue can reflect one of two possibilities: changes in volume at constant prices or changes in revenue from terms-of-trade changes holding volume constant. The difference is crucial, since increased export volume reflects either hard work or alternative costs in terms of consumption forgone, while improved terms of trade unquestionably improve welfare.

Table 2 shows a calculation of the costs and benefits of interest rate and terms-of-trade changes for the group of nonoil developing countries for the period to which the president referred. The first row reports the 
Table 2. Cash-Flow and Welfare Effects in Nonoil LDCs of Terms-of-Trade and Interest Rate Changes, 1983-84

Billions of dollars at annual rate

\begin{tabular}{lccc}
\hline Approach & Trade effect & Debt effect & Net gain \\
\hline Cash-flow & 39.7 & -7.4 & 32.3 \\
Welfare & 21.5 & -21.0 & 0.4 \\
\hline
\end{tabular}

Sources: IMF, Internationai Financial Statistics, and DRI.

a. Period referred to is the first seven months of 1984, compared with the same months in 1983. See text for explanation of figures. If the cash-flow approach had used lagged LIBOR rates as in the welfare approach, a positive debt effect would have been obtained because of a reduction of almost 1 percent in the lagged rate over the period.

numbers, at annual rates, calculated in the manner used by President Reagan: growth in export revenue times the level of LDC exports plus debt outstanding times the increase in the London interbank offer rate, or LIBOR (1.58 percentage points). The net gain to LDCs calculated on this basis is shown as $\$ 32.3$ billion, with trade gains far outweighing the increased interest burden.

The second row shows the calculations consistent with the welfare criterion in equation 3 . These costs and benefits arise from two sources. First, the terms-of-trade improvement appears as a trade gain of $\$ 21.5$ billion, arrived at by multiplying the percentage improvement in the terms of trade times the initial import level. Because export volume growth is not reckoned, the trade gain comes to only about one-half that in the first row.

The second effect, the welfare cost of the increase in interest rates, or the decrease in the real discount factor, is given by initial debt plus the current account deficit times the change in the real discount factor. Because of the large change in the real discount factor-a decline from 0.90 to 0.83 , yielding a proportional change of 7.5 percent-the welfare cost of increased debt service comes to nearly $\$ 39$ billion. ${ }^{5}$ This cost, however, is in part offset by the realized reduction in the real value of the initial debt due to the increase in export prices between 1983 and 1984. Against the cost of $\$ 39$ billion stands a benefit of $\$ 17.8$ billion,

5. The real discount factor is calculated as $R^{*}=\left[1+4\left(P_{t+3} / P_{t-1}\right)\right] /\left(1+i^{*}{ }_{t-6}\right)$, where $P$ is the export unit value and $i^{*}$ the three-month LIBOR stated at an annual rate. The real discount factor uses the forward rate of inflation but the lagged LIBOR, since institutionally current interest charges are based on the six-month lagged LIBOR. The reader who feels cheated by the use of export unit values as a deflator should remember that equation 3 is derived in this fashion. Alternatively, had import unit values been used, given the termsof-trade improvement, the shift in real interest rates would have been even higher. 
leaving a total debt cost of $\$ 21.0$ billion. The net effect corrects for the reduction in the initial real value of the debt by realized capital gains but takes into account the income forward-looking equivalent of higher real interest rates. The second row of table 2 shows that the debt cost almost exactly offsets the terms-of-trade gain, so that on welfare-based calculation there is practically no change in welfare, as against a sweeping $\$ 32$ billion change on the incorrect calculation. ${ }^{6}$

Before leaving these calculations it is worth emphasizing the main points. First, there is no question that improvement in the terms of trade, not export revenue growth, is the vehicle for welfare improvement. Volume, if it matters at all, must be given a shadow price. Second, the real interest rate, not the nominal rate, matters for welfare. Whatever questions there might be about averaging capital gains on outstanding debt over longer periods, there is no question that welfare is affected by the real rate, which is the intertemporal terms of trade. The exact numbers in table 2 are surely sensitive to the exact time period, since the export price series is highly variable. The interest of the calculation therefore lies in demonstrating principles, not in welfare judgments for a particular historical period.

The welfare analysis so far assumes the complete absence of distortions that may modify in an important way the welfare criterion. Up to this point, terms-of-trade changes, capital gains or losses, and real interest rate changes are the only determinants of welfare change. From that perspective there has been little change in welfare. The analytical framework and welfare calculations show that comparing increased export revenue with the cost of increased debt service due to nominal interest rate changes makes no sense whatsoever. I now turn to qualifications that arise from credit rationing and imperfect wage-price flexibility.

\section{COMPLICATIONS}

Foreign disturbances have additional effects on home welfare when they interact with distortions in the competitive allocation of resources.

6. The nonoil LDC's initial conditions used in the calculation are the following: initial debt (floating rate) is assumed to be $\$ 470$ billion; exports, $\$ 324$ billion; imports, $\$ 370$ billion; and the current account deficit, $\$ 50$ billion. Terms-of-trade improvement is assumed to be 5.8 percent; and an increase in export prices between 1983 and 1984 (average of the first seven months in each period), 3.8 percent. The percentage change in the real discount factor is $\mathrm{d} R^{*} / R^{*}=100(0.83-0.897) / 0.897=7.47$ percent. 
These distortions may take the form of tariffs or quotas, imperfect competition, or departures from constant returns to scale. They may also exist in the world capital market. Access to credit may be rationed so that the productivity of capital and the marginal rate of substitution between present and future consumption diverge from the world interest rate. Less than full wage-price flexibility is a separate source of distortion.

In principle it is possible to adapt the welfare criterion in equation 3 to the case of distortions. The result, however, is specific to the particular distortion at hand, so that there is no general case. Except for the case of credit rationing, which I use for illustrative purposes, I therefore limit the discussion to the direction in which these distortions tilt the welfare change rather than presenting formulas or outright estimates. As a general rule, the effect is to complement the terms-of-trade and debt effects already discussed.

For a simple illustration of the welfare implications of credit rationing, I assume that credit rationing is the only distortion and that initial debt is zero. As the appendix shows, the welfare change is now:

$$
\begin{aligned}
\Delta W= & -\Sigma M_{i} \mathrm{~d} p_{i}-R^{*}(1-\gamma) \Sigma M_{i}^{t+1} \mathrm{~d} p_{i}^{t+1} \\
& +(1-\gamma) J\left(\frac{\mathrm{d} R^{*}}{R^{*}}\right)+\gamma \mathrm{d} J
\end{aligned}
$$

where $\gamma$ denotes the ratio of the domestic discount factor under rationing to the international discount factor $R^{*}$. Hence $\gamma$ is a positive fraction, since the shadow rate of interest under rationing exceeds that available in the world market under unrestricted borrowing. The term $J$ denotes the first period current account deficit, which is restricted by credit rationing. The term $J$ thus denotes the available credit line, and it is assumed that the credit constraint is effective.

The revised welfare criterion takes into account that under credit rationing there is insufficient consumption-smoothing and insufficient investment. The welfare effects of rationing appear in two ways. First, a relaxation of existing rationing yields an increase in welfare by raising the level of current consumption and of investment, the activities whose domestic valuation exceeds the world cost. This effect is captured in the term $\gamma \mathrm{d} J$. The resulting improvement in domestic demand leads to an improvement in the terms of trade that further increases the welfare gain of the reduced restriction. Second, the presence of rationing increases the costs of adverse external shocks. 
The importance of credit rationing becomes particularly clear in the case of cyclical fluctuations in the terms of trade. Equation 3 shows that in the absence of any distortion a small deterioration in the current terms of trade can be offset by a future improvement of equal size (including interest), with welfare unchanged. But when credit is rationed the smoothing of consumption that makes for a zero net welfare effect cannot take place. As a result, terms-of-trade fluctuations become costly, as seen in equation $3 \mathrm{a}$, where a future terms-of-trade improvement is weighted by the factor $(1-\gamma) R^{*}$, being discounted at the shadow interest rate. In this case, the offsetting future terms-of-trade improvement must be larger than the current deterioration.

When credit is rationed, transitory disturbances cannot be optimally adjusted to by borrowing. Too much of the real income deterioration has to be absorbed by cuts in current consumption and investment; too little, by borrowing. The costs go further in this sense: because credit rationing restricts current consumption and investment, it causes an adverse shock to translate into a larger reduction in the real price of domestic manufactures. Thus the secondary burdens of adverse shocks tend to be enlarged. By contrast, favorable shocks tend to have larger beneficial welfare effects, since they tend to reduce the marginal welfare cost of credit rationing.

Less than full wage-price flexibility implies that adverse shocks lead to unemployment. When a cut in real disposable income leads to reduced spending on domestic goods, the spending cuts translate into reduced production and employment, which feed on themselves with multiplier effects. In the case of transitory shocks, the high costs of credit rationing emerge once more, because they imply that a fall in current disposable income results in more unemployment and a larger loss in welfare than would be the case with unrestricted borrowing.

\section{FOREIGN DEMAND}

The next question is whether distortions affect the role that foreign demand plays in relation to home welfare. As noted above, in the undistorted case, an increase in foreign demand raises welfare only to the extent that it leads to an increase in the equilibrium real price of exportables. The increase in export earnings holding volume constant fully accounts for the benefits of the shock. Any increase in export volume itself leads to no benefit in this undistorted case. 
Once distortions are introduced, an increase in foreign demand does carry extra welfare benefits. If the home export sector is imperfectly competitive, price exceeds marginal cost. An increase in foreign demand will raise welfare by the profit margin times the increase in sales volume. Now, because, by definition, the imperfect competitor underproduces, the export sector will be able to increase sales without sacrificing profits.

With imperfect wage flexibility, increased foreign demand dispenses with the need to use domestic exchange rate or fiscal policies, which may themselves be costly or even impossible to achieve, to maintain full employment. For example, a devaluation, because of its inflationary impact, may appear as an excess burden of adjustment to a disturbance. Here is perhaps the most important role for foreign demand. If policy obstacles or inflexibility prevents relative price changes that assure full employment, then foreign demand can fill the gap and avoid excess costs.

A decline in foreign demand, of course, reduces welfare. Such a decline might occur as a result of a recession abroad, but it might also occur as a result of protection. In either event, lower world demand leads to a deterioration in an LDC's terms of trade and hence a loss in welfare. The issue arises in a particularly forceful way when an adverse shock forces a deterioration in the LDC's full-employment terms of trade, to which developed countries respond by tariffs, which in turn further depress the terms of trade.

Credit rationing does not give foreign demand a special role, as can be noted from equation $3 \mathrm{a}$. It might be thought that credit rationing implies a foreign exchange shortage that is mitigated by increased foreign demand. But, in fact, as long as there is full wage-price flexibility, there is nothing special about foreign exchange: resources are fungible, and credit rationing implies a shortage of current resources, not foreign resources. Thus foreign demand issues come into their own only when resources are not fungible or when it is costly to pursue resource reallocation.

Once distortions are present because LDCs are constrained in their borrowing ability or because domestic wage-price problems enhance the value of foreign exchange, the welfare calculations need amending. Clearly the net costs reported in table 2 now will be less. If the shadow price of an extra dollar of foreign exchange is sufficiently high, growth in export volume can make a decisive difference to welfare, and there might even be a welfare improvement. On the other hand, the conditions 
that lead to a high shadow price also argue against rapid servicing of the debt and in favor of loans. One cannot on the same welfare criterion claim that export volume growth improves welfare and that LDCs are better off reducing their debt rapidly. To do so is to sanction credit rationing as not being costly. The primary reason export volume matters in the case of credit rationing is that increased volume permits extra credit and improves access to foreign exchange. Given foreign exchange, a country can expand current demand to use its resources fully.

A final caveat concerning foreign demand is this: foreign demand growth certainly cannot hurt; it improves the terms of trade and profits. But export volume growth need not necessarily reflect growth in foreign demand. It can just as well be a reflection of a domestic recession or of forced and premature debt service. Thus strong export volume growth cannot automatically be treated as an improvement in welfare, and under no circumstances as a one-for-one trade-off, as is so often done in a simple counting of export revenue.

\section{The Structure of LDC Trade and Debt}

The preceding section has identified the channels through which foreign disturbances affect LDC welfare. This section examines the trade and debt structure of individual LDCs to see which disturbances are likely to be important for which particular country or group of countries.

\section{TRADE STRUCTURE}

The terms of trade is one potentially important channel of external influence on domestic welfare. In particular, changes in the world real price of primary commodities are important for those countries that are either large net importers or net exporters. The same argument applies, of course, not only to primary commodities, but also to petroleum.

Before the 1960s, LDCs tended to export primary commodities and import manufactures. That picture has changed in two respects. First, petroleum has assumed a large share in many countries' trade. Second, in a longer term trend, the LDC import share of manufactures has dropped, while the manufactures share in exports has grown. Latin America comes closest to the traditional picture, with primary commod- 
Table 3. Trade Structure for Selected LDCs in 1980-81

Percent of total exports or imports

\begin{tabular}{lccccccc}
\hline & \multicolumn{3}{c}{ Exports } & & \multicolumn{3}{c}{ Imports } \\
\cline { 2 - 3 } \cline { 7 - 8 } Country & $\begin{array}{c}\text { Manu- } \\
\text { factures }\end{array}$ & Oil & $\begin{array}{c}\text { Commod- } \\
\text { ities }\end{array}$ & & $\begin{array}{c}\text { Manu- } \\
\text { factures }\end{array}$ & Oil & $\begin{array}{c}\text { Commod- } \\
\text { ities }\end{array}$ \\
\hline Argentina & 21 & 4 & 75 & & 72 & 10 & 18 \\
Brazil & 35 & 5 & 60 & & 34 & 51 & 15 \\
Chile & 14 & 1 & 85 & & 51 & 21 & 28 \\
Mexico & 12 & 67 & 21 & & 49 & 2 & 49 \\
Indonesia & 3 & 79 & 18 & & 60 & 13 & 27 \\
Korea & 81 & 1 & 12 & & 39 & 30 & 31 \\
Malaysia & 20 & 27 & 53 & & 59 & 17 & 24 \\
Thailand & 25 & 0 & 75 & & 48 & 30 & 22 \\
\hline
\end{tabular}

Source: United Nations Conference on Trade and Development, Handbook of International Trade and Development Statistics, 1984 Supplement (U.N., 1984).

a. Manufactures exclude SITC 67 and 68 , which are ores and metals.

ities accounting for 40.5 percent of exports, manufactures for nearly 60 percent of imports. Asia departs furthest, with manufactures representing nearly 50 percent of total exports. Table 3 shows trade structures for individual countries to identify more precisely the range of differences. Korea and Argentina represent the extremes, with Korea looking "industrialized" and more like Japan, and Argentina resembling a traditional LDC.

The link between LDC trade structure and the analytical results of the preceding section is complicated by the fact that, for some LDCs, intermediate products play an important role in trade. For example, Brazil's manufactures exports include frozen orange juice and processed soya, both of which have a substantial primary commodity content. The prices of these manufactures will therefore move significantly with those of primary commodities rather than with manufactures of industrialized countries. By contrast, Korea's manufactures contain a much higher percentage of labor value added and therefore are much less sensitive to primary commodity prices. These facts are important to bear in mind later when it is shown that there are no uniform linkages between the real price of commodities and particular LDC terms of trade.

\section{EXTERNAL DEBT}

A second major source of external influence on the LDCs is the interest rate on external debt. In the analytical model, changes in interest 
Table 4. External Debt Characteristics of LDC Regions in 1984

Percent unless otherwise specified

\begin{tabular}{lcccc}
\hline & $\begin{array}{c}\text { Total debt } \\
\text { (billions } \\
\text { Region }\end{array}$ & $\begin{array}{c}\text { Rebt- } \\
\text { exports }\end{array}$ & $\begin{array}{c}\text { Debt- } \\
\text { GDP }\end{array}$ & $\begin{array}{c}\text { Interest- } \\
\text { exports }\end{array}$ \\
\hline Latin America & 351.1 & 280 & 46.0 & 28.9 \\
Africa & 126.8 & 162 & 39.8 & 11.3 \\
Asia & 210.9 & 86 & 23.7 & 6.0 \\
\hline
\end{tabular}

Source: IMF, World Economic Outlook, 1985 (IMF, April 1985), tables 45, 48, and 49.

a. Exports denotes exports of goods and services. Debt includes long and short term.

Table 5. External Debt and Debt Service for Selected LDCs in $1984^{\mathrm{a}}$

Percent unless otherwise specified

\begin{tabular}{lccccc}
\hline & $\begin{array}{c}\text { Total debt } \\
\text { (billions } \\
\text { of dollars) }\end{array}$ & $\begin{array}{c}\text { Debt- } \\
\text { exports }\end{array}$ & Debt-GDP & $\begin{array}{c}\text { Bank debt- } \\
\text { total debt }\end{array}$ & $\begin{array}{c}\text { Interest } \\
\text { rate }\end{array}$ \\
\hline Argentina & 47.8 & 483 & 70.6 & 67.0 & 11.8 \\
Brazil & 102.2 & 338 & 48.8 & 77.0 & 11.7 \\
Chile & 20.4 & 424 & 89.1 & 66.7 & 11.0 \\
Mexico & 96.7 & 309 & 60.5 & 79.9 & 12.5 \\
Indonesia & 30.9 & 150 & 37.3 & 46.0 & 6.9 \\
Korea & 45.0 & 134 & 53.6 & 68.7 & 9.2 \\
Malaysia & 18.1 & 95 & 55.4 & 61.9 & 7.2 \\
Thailand & 14.7 & 154 & 35.0 & 50.5 & 10.0 \\
\hline
\end{tabular}

Sources: Unpublished data from Morgan Guaranty, and IMF, International Financial Statistics.

a. The effective interest rate is estimated as interest payments expressed as a fraction of debt outstanding. The debt-export ratio for Indonesia refers to 1983.

rates change welfare in proportion to the stock of debt outstanding. Table 4 shows data for outstanding debts, absolutely and relative to exports and GDP, for three regions. The table also reports interest payments as a fraction of exports, a measure that, in conjunction with the debt-export ratio, gives an idea of how debt is divided between official debt at concessional or fixed rates and bank debt, which tends to be serviced at a market-linked floating rate.

The table brings out the large regional differences in indebtedness and thus highlights the importance of interest rate shocks in helping explain differential performance. Table 5 shows the data in a more disaggregated form and includes an estimate of the effective interest rate paid by each country on external debt. This effective rate is calculated as the ratio of total interest to total debt outstanding and thus is a weighted 
average over the various kinds of debt: short-term and long-term, bank and official, dollar and shekel. It can be compared with a 1984 average LIBOR rate of 10.5 percent.

The detailed comparison shows that major borrowers in Latin America have a significantly higher share of bank debt and a much larger ratio of debt to exports or GDP than do Asian countries. The higher average interest rate also reflects, presumably, much higher spreads over LIBOR than is the case for Asia. As a result, Latin America's exposure to interest rate shocks is much greater than that of Asia.

The informal table below combines the different elements to summarize the differences in structure with respect to trade and debt in the group of nonoil LDCs. The effect of macroeconomic events in the OECD countries on LDCs will vary, depending on each country's peculiar debtor-trader make-up.

Net exporters of materials

Net importers of materials
Ratio of bank debt to exports

\begin{tabular}{lll}
\hline High & Medium & \multicolumn{1}{c}{ Low } \\
Brazil & Peru & Sri Lanka \\
Chile & Korea & Hong Kong
\end{tabular}

\section{Quantifying the Linkages}

From the conceptual framework and the trade and debt structure, I now turn to an attempt to quantify the linkages between OECD macroeconomics and the LDCs. The paradigm of performance linkages during the 1950s and 1960s was "trade as an engine of growth." The potential of trade to transmit growth from rich to poor countries is emphasized in the Nurkse-Haberler-Lewis approach, although the adequacy of the transmission and its persistence have at various times been questioned. Thus W. Arthur Lewis has documented the growth transmission but also argued the need for auxiliary engines of growth, such as import substitution at the national or regional level, if the LDCs are to continue growing at satisfactory rates. ${ }^{7}$ Still, the broad pattern in the economic

7. See W. Arthur Lewis, "The Slowing Down of the Engine of Growth," American Economic Review, vol. 70 (September 1980), pp. 555-64; I. B. Kravis, "Trade as the Handmaiden of Growth: Similarities between the Nineteenth and Twentieth Centuries," Economic Journal, vol. 80 (December 1970), pp. 850-72; Lloyd G. Reynolds, "The Spread of Economic Growth to the Third World: 1850-1980," Journal of Economic Literature, 
relationship between LDCs and the OECD countries is summarized by the fact that sustained high economic growth at the center promotes growth at the periphery.

Table 6 shows the results of three regressions testing the relation between the growth of real gross domestic product in the nonoil LDCs and the growth rate of OECD countries. The equations differ in that they use alternative measures of OECD growth, namely the growth rates of industrial production, real GDP, and import volume, as explanatory variables. In each case the explanatory variable is entered as a distributed lag.

These regressions confirm that sustained growth in the OECD countries spreads to LDCs and raises growth there. The precise magnitude of the impact is quite open, and so is the question of which of the three measures of OECD growth is the best indicator of the spread of prosperity. Import growth is certainly too limited a measure, because it entirely leaves out the role played by international capital flows to LDCs, which are themselves a by-product of the spreading prosperity. As OECD growth touches LDCs, their external balance position improves, or their creditworthiness as of given debts is enhanced. As a result, access to more capital becomes available, which in turn makes it possible to finance growth-enhancing policies of investment even if these projects have large import content.

This broad approach uses OECD growth as a proxy for the several separate channels, including interest rates and the terms of trade, through which OECD macroeconomics exerts an effect on the LDCs. But since the trade and debt structure differs from one LDC to another, and since the same growth rate for the aggregate OECD is consistent with different interest rates, exchange rates, and commodity prices, it is necessary to look at the more disaggregated linkages, taking each of the channels identified above in turn.

\section{THE TERMS OF TRADE}

One of the old questions in LDC-industrial country discussions concerns the terms of trade of the periphery. That question was well

vol. 21 (September 1983), pp. 941-80; and James Riedel, "Trade as the Engine of Growth in Developing Countries, Revisited," Economic Journal, vol. 94 (March 1984), pp. 56-73. The older literature includes in particular Ragnar Nurkse, Patterns of Trade and Development (Stockholm: Almquist and Wicksell, 1959), and Gottfried Haberler, International Trade and Economic Development (National Bank of Egypt, 1959). 
Table 6. Trade as the Engine of Growth in Nonoil LDCs, 1961-84a

\begin{tabular}{|c|c|c|c|c|c|}
\hline \multirow[b]{2}{*}{$\begin{array}{l}\text { Measure of } \\
\text { OECD growth }\end{array}$} & \multirow[b]{2}{*}{ Constant } & \multirow[b]{2}{*}{$\begin{array}{l}\text { OECD } \\
\text { growth }\end{array}$} & \multicolumn{3}{|c|}{ Summary statistic } \\
\hline & & & Rho & $R^{2}$ & $\begin{array}{l}\text { Durbin- } \\
\text { Watson }\end{array}$ \\
\hline Industrial production & 2.25 & $\begin{array}{c}0.76 \\
(2.54)\end{array}$ & 0.46 & 0.49 & 1.72 \\
\hline Real GDP & 3.37 & $\begin{array}{c}0.34 \\
(2.80)\end{array}$ & 0.50 & 0.51 & 1.80 \\
\hline Import volume & 2.90 & $\begin{array}{l}0.28 \\
(2.98)\end{array}$ & 0.44 & 0.56 & 1.85 \\
\hline
\end{tabular}

a. The dependent variable is growth of real GDP in nonoil LDCs. Numbers in parentheses are $t$-statistics. The explanatory variables are entered as distributed lags. The table reports the sums of the estimated coefficients.

defined when the periphery was an area in which raw materials were produced and the center was producing manufactures. With trade patterns so clearly defined, it made sense to ask how the gains from trade are shared between rich and poor countries. These themes were particularly developed in the context of the challenge to the classical theory of the gains from trade offered by the Prebisch-Singer thesis, which argues that LDCs are particularly exposed as exporters of materials. ${ }^{8}$ Specifically, the argument is that a cyclical downturn in OECD countries reduces real commodity prices sharply, because both the demand and supply price elasticities are low in the short run. In the longer run, real commodity prices are said to decline because of low income elasticities of demand and high growth rates of productivity on the supply side.

Today it is no longer the case that LDCs are uniformly producers of materials and importers of manufactures. Hence their terms of tradethe ratio of export to import prices-no longer merely reflect the behavior of the real price of commodities in terms of manufactures. Figure 3 makes that point by showing two series. The solid line shows the terms of trade of all nonoil LDCs, while the dashed line represents the Economist index of commodities (excluding oil) deflated by the export price index of industrialized countries. ${ }^{9}$

The two series share some of the major trends, but there are differ-

8. See H. W. Singer, "The Terms of Trade Controversy and the Evolution of Soft Financing: Early Years in the U.N.," in Gerald M. Meier and Dudley Seers, eds., Pioneers in Development (Oxford University Press, 1984), pp. 275-303; and Report by the Secretary General of Unctad, Toward a New Trade Policy for Development (New York: United Nations, 1964). See also John Spraos, Inequalising Trade? (Clarendon Press, 1983).

9. The export price of industrialized countries is represented by the export unit value. The export unit value matches closely the behavior of manufactures prices in world trade. 
Figure 3. The Nonoil LDCs' Terms of Trade and the Real Commodity Price, 1974:1-1985: $1^{\text {a }}$

Index, $1980=100$

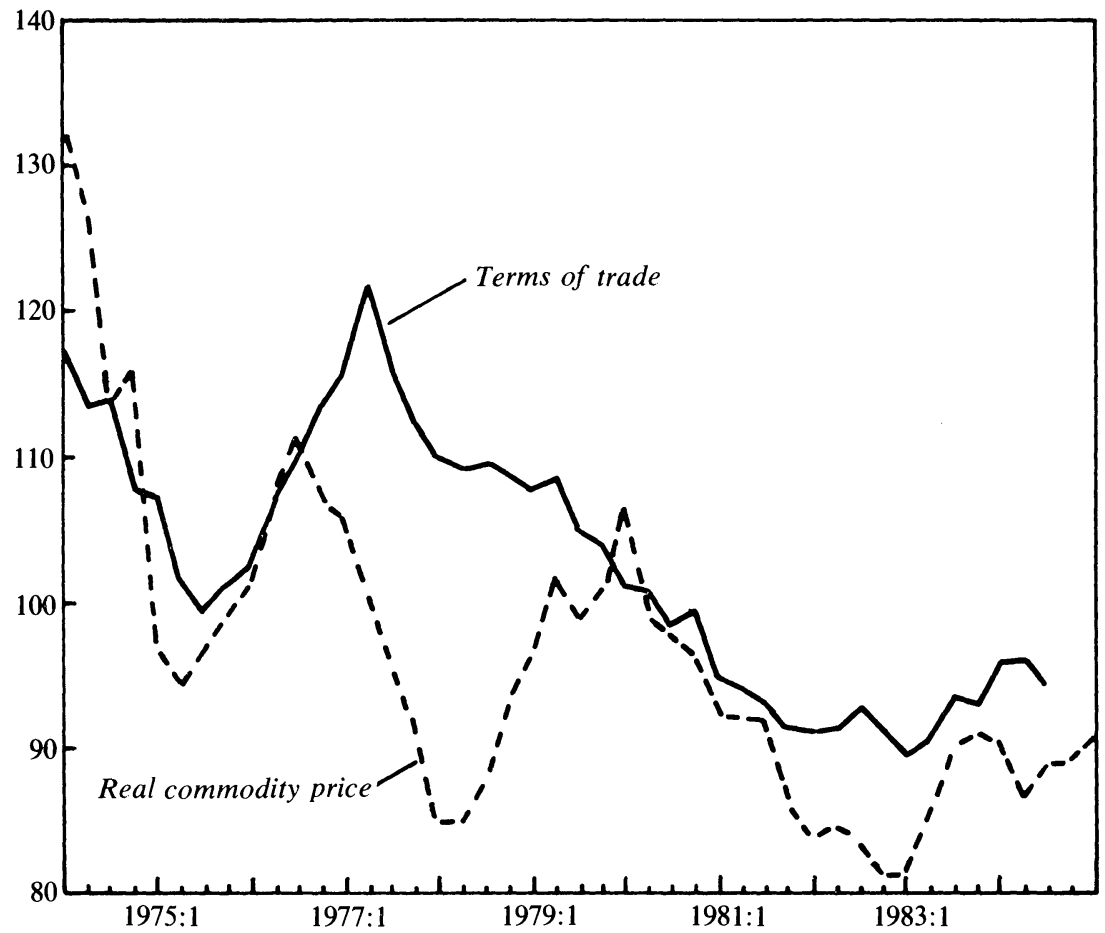

Sources: The Economist, and International Monetary Fund, International Financial Statistics.

a. The real commodity price is the Economist index of commodities deflated by industrial countries' unit export values. Terms of trade are exports unit value index divided by imports unit value index. Terms-of-trade data extend through 1984:3.

ences, for example in 1979-80, in the behavior and certainly in the magnitude of swings. Part of the difference is accounted for by oil prices, which enter the terms-of-trade, but not the real commodity price, series. But in the main the lack of conformity of the two series arises from the fact that the terms of trade simply are no longer tantamount to the ratio of commodity to manufactures prices. In fact, figure 3 makes it clear that the LDCs' terms of trade are much more stable than the real price of commodities.

Table 7 investigates the determinants of the terms of trade by means of three regressions. The first regression shows results for all nonoil LDCs; the second and third, for Brazil and Korea. Using quarterly data 
Table 7. The Determinants of the Terms of Trade for Nonoil LDCs, 1973:1-1984:3a

\begin{tabular}{|c|c|c|c|c|c|c|}
\hline \multirow[b]{2}{*}{ Country } & \multirow[b]{2}{*}{ Constant } & \multirow{2}{*}{$\begin{array}{l}\text { Real nonoil } \\
\text { commodity } \\
\text { price }\end{array}$} & \multirow[b]{2}{*}{$\begin{array}{c}\text { Real price } \\
\text { of oil }\end{array}$} & \multicolumn{3}{|c|}{ Summary statistic } \\
\hline & & & & Rho & $R^{2}$ & $\begin{array}{l}\text { Durbin- } \\
\text { Watson }\end{array}$ \\
\hline All nonoil LDCs & 3.39 & $\begin{array}{c}0.30 \\
(3.62)\end{array}$ & $\begin{array}{c}-0.09 \\
(-3.50)\end{array}$ & 0.89 & 0.94 & 2.09 \\
\hline Brazil & 7.51 & $\begin{array}{c}0.81 \\
(3.59)\end{array}$ & $\begin{array}{c}-0.26 \\
(-2.79)\end{array}$ & 0.76 & 0.88 & 2.24 \\
\hline Korea & 3.04 & $\begin{array}{c}-0.22 \\
(-2.58)\end{array}$ & $\begin{array}{c}-0.10 \\
(-2.71)\end{array}$ & 0.90 & 0.92 & 1.83 \\
\hline
\end{tabular}

a. The dependent variable is $\log$ (terms of trade). Independent variables are logs. Numbers in parentheses are $t$ statistics. All regressions corrected for first order serial correlation. For Brazil the export unit value is that of noncoffee exports. The explanatory variables are entered as distributed lags. The table reports the sums of the estimated coefficients.

for the period 1973:1-1984:3, I regressed the level of the log of the termsof-trade index $(T O T)$ on the log of the real nonoil commodity or materials price $(R M P)$, and on the log of the real price of oil in terms of industrial countries' export unit values $(R O P)$.

Even though LDCs now have manufactures on both the export and import side and the net impact of the commodities-manufactures relative price, $R M P$, is opposite in Brazil and Korea, a rise in the real price of commodities improves the group's terms of trade. But the elasticity now is relatively small, only 0.21 . The real price of oil enters with a negative sign, since this group is made up of net importers of oil. Here the elasticity for the group is even smaller.

Note that for Brazil and Korea, both oil-importing countries, the real price of oil appears with a negative coefficient. But for Brazil and Korea real material prices have elasticities of opposite signs, reflecting the fact that the former is a net exporter, whereas the latter is a net importer. The elasticity estimates also differ significantly in size: Brazil's terms of trade are much more responsive to both real oil and real commodity prices than are those of Korea.

The difference between these two countries is strongly brought out in figure 4, which shows for Brazil a sharp terms-of-trade deterioration in the 1977-81 period. The series shown in the diagram includes coffee and reflects the 1976-77 coffee boom in a sharp terms-of-trade improvement for Brazil. For Korea the decline in commodity prices at the end of the 1970s offsets the second oil shock, whereas for Brazil it reinforces it. 
Figure 4. The Terms of Trade of Korea and Brazil, 1973:1-1985:1 ${ }^{\text {a }}$

Index, $1980=100$

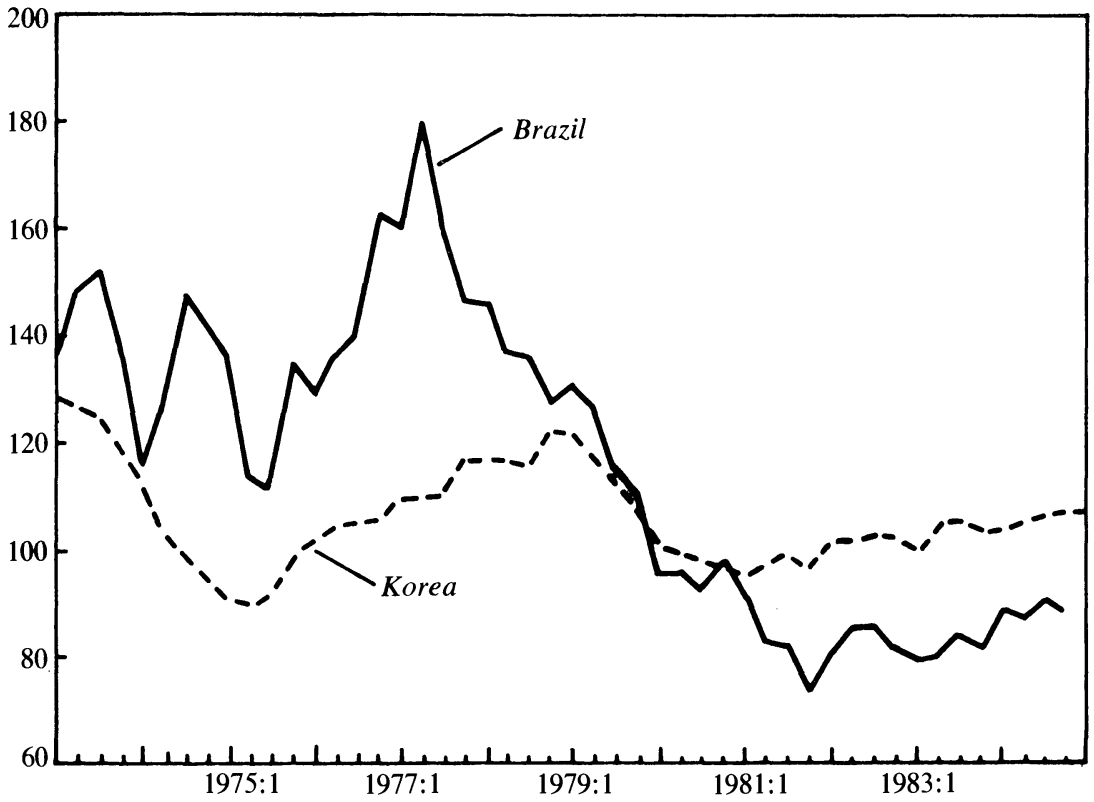

Source: IMF, International Financial Statistics.

a. Defined as price of exports divided by price of imports (unit value index), and calculated as a three-quarters centered moving average. Data for Brazil extend through 1984:4.

\section{THE REAL PRICE OF COMMODITIES}

The question now is what determines the real price of commodities. Figure 5 shows quarterly data since 1960 for the real price of commodities in terms of the export unit values of industrialized countries. These are close but not identical to the manufactures unit value. Shown on the horizontal axis are the peaks and troughs of the international business cycle derived for the seven major industrialized countries by Geoffrey Moore and Victor Zarnowitz. ${ }^{10}$ The timing of movements in real commodity prices corresponds broadly to the business cycle. But that correspondence is not always exact. Moreover, there are some instances,

10. See Geoffrey H. Moore and Victor Zarnowitz, "The Development and Role of the National Bureau's Business Cycle Chronologies," Working Paper 1394 (National Bureau of Economic Research, July 1984). 


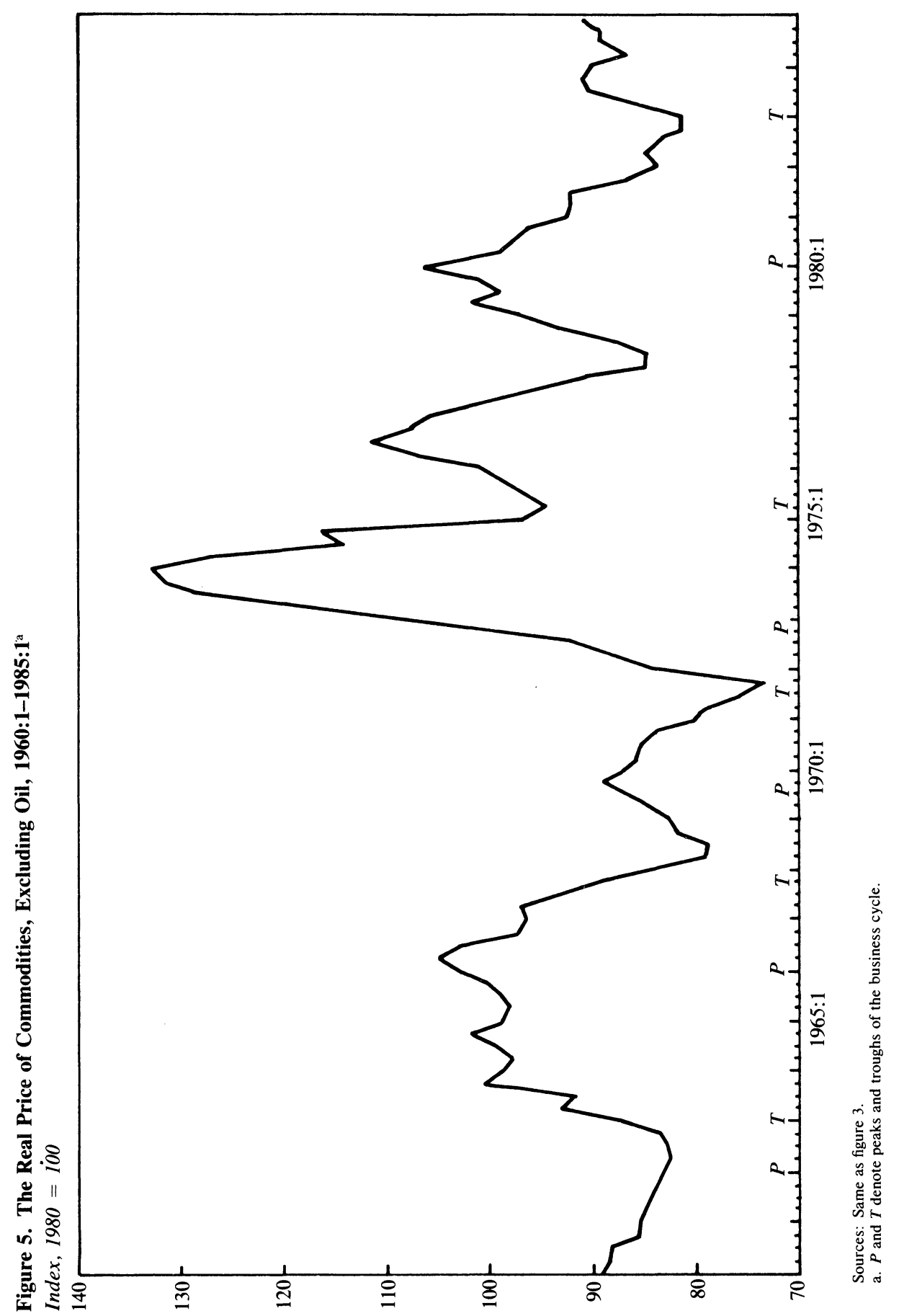


for example, 1978, where a dip in the real commodity price has no counterpart in the business cycle. In fact, 1978 was a year of strong expansion in world industrial production.

Table 8 shows the trough-to-peak change in both world industrial production and real commodity prices. Real commodity prices are measured alternatively by the Economist and the IMF index of prices for all commodities, in each case deflated by the industrial countries' export unit value. The table demonstrates that the cyclical factor by itself is not sufficient to explain the behavior of commodity prices: in some recoveries real prices fall, and across recoveries the rates of increase differ widely.

Commodity prices can, however, be explained by a model that includes two other determinants of real commodity prices. One is supplyside factors for individual commodities, which affect both the trend and the short-run volatility of the prices. For example, between 1975 and 1978 the price of coffee tripled, and even though the share of coffee in the overall index is small, the price explosion affects the aggregate index. The other is the real exchange rate of the U.S. dollar. A strengthening of the dollar tends to lower the real price of commodities.

Equation 4 reports a regression using quarterly data for the period 1970:2 to 1984:4 of the rate of change of real commodity prices (RMP) on the rate of appreciation of the U.S. dollar $(R D O L)$ and on the growth rate of industrial production of the $\operatorname{OECD}(A C T){ }^{11}$

$$
\begin{aligned}
R M P= & -1.44+2.07 A C T-0.82 R D O L \\
& (-2.06) \quad(3.56) \quad(-1.94) \\
& R^{2}=0.35 ; \text { Durbin-Watson }=1.90 .
\end{aligned}
$$

The equation confirms the expected positive effect of OECD growth on real commodity prices. More surprising is the effect of the real exchange rate appreciation. That effect in different specifications is invariably negative, although it is not always significant. One would expect changes in the dollar exchange rate to affect the nominal prices of both commodities and manufactured goods in world trade in the same

11. The U.S. real exchange rate is given by the IMF's index of relative value-added deflators in manufacturing; industrial production, by the IMF's index for all industrialized countries. The regression is run in first differences with the explanatory variables entered as distributed lags. Numbers in parentheses are $t$-statistics. 
Table 8. Cyclical Behavior of Real Commodity Prices, 1958:2-1980:1 ${ }^{\mathrm{a}}$

Percentage change, trough to peak

\begin{tabular}{lcccr}
\hline & Cycle & & $\begin{array}{c}\text { Industrial } \\
\text { production in } \\
\text { industrialized } \\
\text { countries }\end{array}$ & \multicolumn{2}{c}{$\begin{array}{c}\text { Real nonoil } \\
\text { commodity prices }\end{array}$} \\
\cline { 1 - 4 } $\begin{array}{l}\text { Trough } \\
\text { quarter }\end{array}$ & $\begin{array}{c}\text { Peak } \\
\text { quarter }\end{array}$ & 21.5 & $\begin{array}{c}\text { Economist } \\
\text { index }\end{array}$ & $\begin{array}{c}\text { IMF } \\
\text { index }\end{array}$ \\
\hline $1958: 2$ & $1960: 1$ & 10.4 & -1.9 & -0.1 \\
$1961: 1$ & $1962: 1$ & 26.3 & -2.7 & -1.6 \\
$1963: 1$ & $1966: 1$ & 14.3 & 18.0 & 10.8 \\
$1967: 4$ & $1969: 3$ & 19.5 & -3.4 & 4.7 \\
$1971: 3$ & $1973: 4$ & 30.6 & 74.0 & 40.9 \\
$1975: 2$ & $1980: 1$ & & 10.1 & 15.9 \\
\hline
\end{tabular}

Sources: Geoffrey H. Moore and Victor Zarnowitz, "The Development and Role of the National Bureau's Business Cycle Chronologies," Working Paper 1394 (National Bureau of Economic Research, July 1984); IMF, International Financial Statistics; and DRI.

a. Commodity prices are deflated by the industrial countries' exports unit value.

direction, not to change the real price of commodities. A dollar appreciation would be expected to lower the purchasing power of commodities in terms of U.S. goods while raising it in terms of other industrial countries' output, with no significant net effect. The presence of a negative coefficient, however, suggests that on balance the purchasing power of commodities declines in terms of manufactures. An explanation of that effect requires a more complete model of the purchasing power of commodities in terms of the goods of the United States and other industrialized countries. ${ }^{12}$

A Model. The world market for commodities is assumed to be integrated. There are two consuming regions, the United States and the

12. For empirical work on commodity prices, see Barry P. Bosworth and Robert Z. Lawrence, Commodity Prices and the New Inflation (Brookings, 1982); Richard N. Cooper and Robert Z. Lawrence, "The 1972-75 Commodity Boom," BPEA, 3:1975, pp. 671-715;

$\rightarrow$ Ke-Young Chu and Thomas K. Morrison, "The 1981-82 Recession and Non-Oil Primary Commodity Prices," IMF Staff Papers, vol. 31 (March 1984), pp. 93-1 $\rightarrow$ Andrew Feltenstein, Morris Goldstein, and Susan M. Schadler, "A Multilateral Exchange Rate Model for Primary Producing Countries," IMF Staff Papers, vol. 26 (September 1979), pp. 543-82; and A. Steven Englander, "Commodity Prices in the Current Recovery," Federal Reserve Bank of New York Quarterly Review, vol. 10 (Spring 1985), pp. 11-19.

The role of the U.S. real exchange rate in influencing commodity prices is emphasized in Rudiger Dornbusch, "Flexible Exchange Rates and Interdependence," IMF Staff Papers, vol. 30 (March 1983), pp. 3-30; Jeffrey Sachs, "Macroeconomic Policies in the OECD and LDCs' External Adjustment" (Harvard University, September 1984), and “The Dollar and the Policy Mix: 1985,' BPEA, 1:1985, pp. 117-85; and Rudiger Dornbusch, "The Effects of OECD Macroeconomic Policies on Non-Oil LDCs: A Review" (Massachusetts Institute of Technology, 1984). 
rest of the world. The rest of the world is always viewed as "the" foreign country and denoted by an asterisk. World demand for commodities depends on the real price of commodities in terms of the GDP deflators in each of the two regions and on real activity. The supply of commodities is assumed exogenous.

$$
S=D\left(\frac{P_{c}}{P}, Y\right)+D^{*}\left(\frac{P_{c}^{*}}{P^{*}}, Y^{*}\right)
$$

where

$Y, Y^{*}$ are domestic and foreign activity

$P_{c}, P_{c}^{*}$ are commodity prices in home and foreign currency

$P, P^{*}$ are the domestic and foreign deflators in the respective currencies.

It is assumed that materials or commodity prices are arbitraged so that their price, measured in dollars, is spatially equalized:

$$
P_{c}=e P_{c}^{*} .
$$

The U.S. real exchange rate is defined as the ratio of the U.S. deflator (in manufacturing) to the deflator of U.S. trading partners, measured in dollars, $P / e P^{*}$. When equation 6 is substituted in equation 5 , the solution for the real commodity price in terms of activity, supply, and the real exchange rate is:

$$
\frac{P_{c}}{P}=H\left(Y, Y^{*}, \frac{P}{e P^{*}} ; S\right), H_{1}, H_{2}>0 ; H_{3}<0 .
$$

The model is shown in figure 6 . The schedule $D+D^{*}$ represents world demand, drawn for a given real exchange rate and a given level of world activity. The initial equilibrium real price is $\left(P_{c} / P\right)_{0}$.

The model implies that an increase in activity raises real commodity prices. This is the cyclical effect that until recently was the major macroeconomic effect noted in work on commodity prices. But equation 5 also shows a role for the real exchange rate: a real appreciation of the U.S. dollar will lower real commodity prices in terms of the U.S. deflator while raising them in terms of foreign deflators.

The result can be understood in the following terms. Suppose the GDP deflator in each country is given and the exchange rate moves. At a given domestic price of commodities the real price at home would be 
Figure 6. World Commodity Market

Relative price

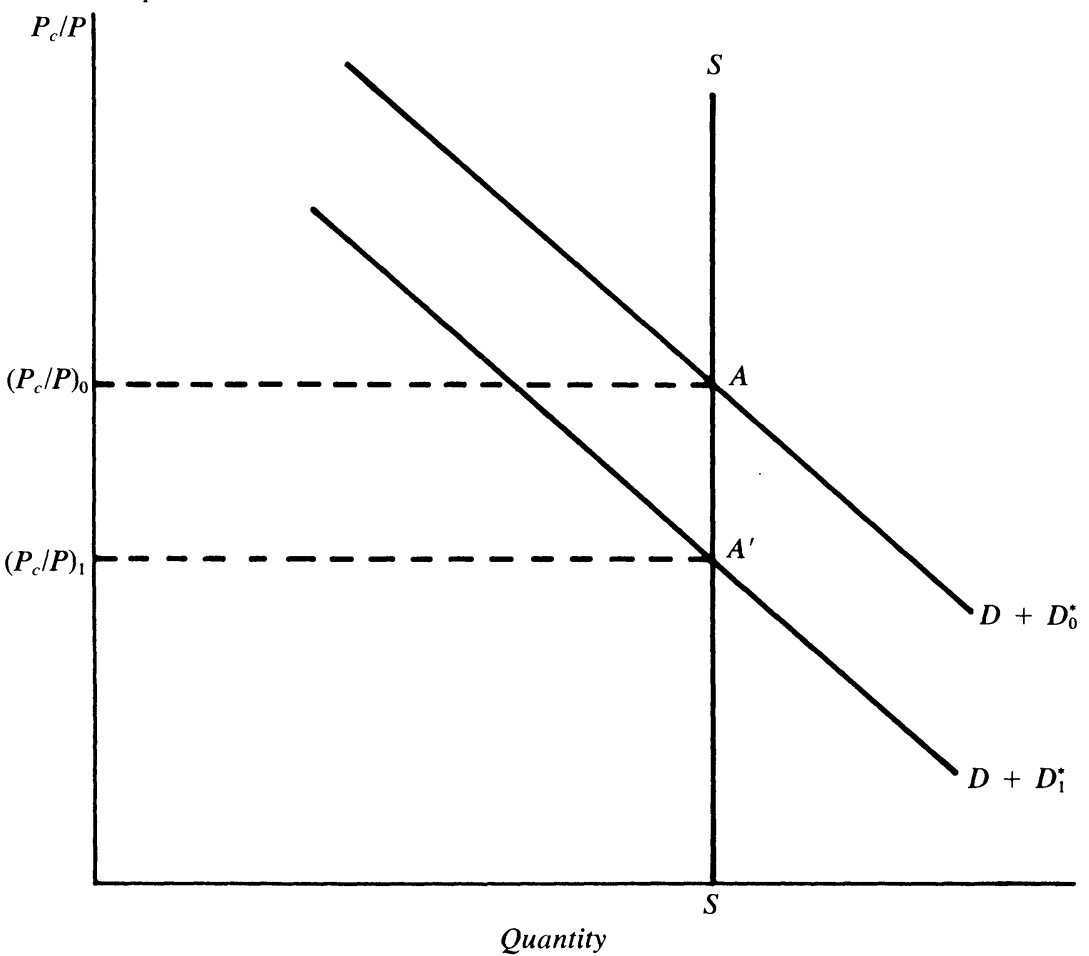

unchanged. But with the dollar appreciation, the foreign price of commodities is now higher and so is the real price abroad. Consequently, quantity demand abroad declines, and there is a world excess supply, as shown by the downward shift of the world demand schedule in figure 6 . To restore equilibrium the real price in terms of the U.S. deflator must fall to $\left(P_{c} / P\right)_{1}$.

Moreover, from equation 5, the percentage change in the equilibrium price due to a real dollar appreciation is equal to:

$$
\frac{\partial \ln \left(\frac{P_{c}}{P}\right)}{\partial \ln \left(\frac{P}{e P^{*}}\right)}=\frac{\frac{-\beta^{*}}{\eta^{*}}}{\left(\beta \eta+\beta^{*} \eta^{*}\right)},
$$


Figure 7. The Real Price of Commodities, United States and Germany, 1970:1-1985: $1^{\text {a }}$

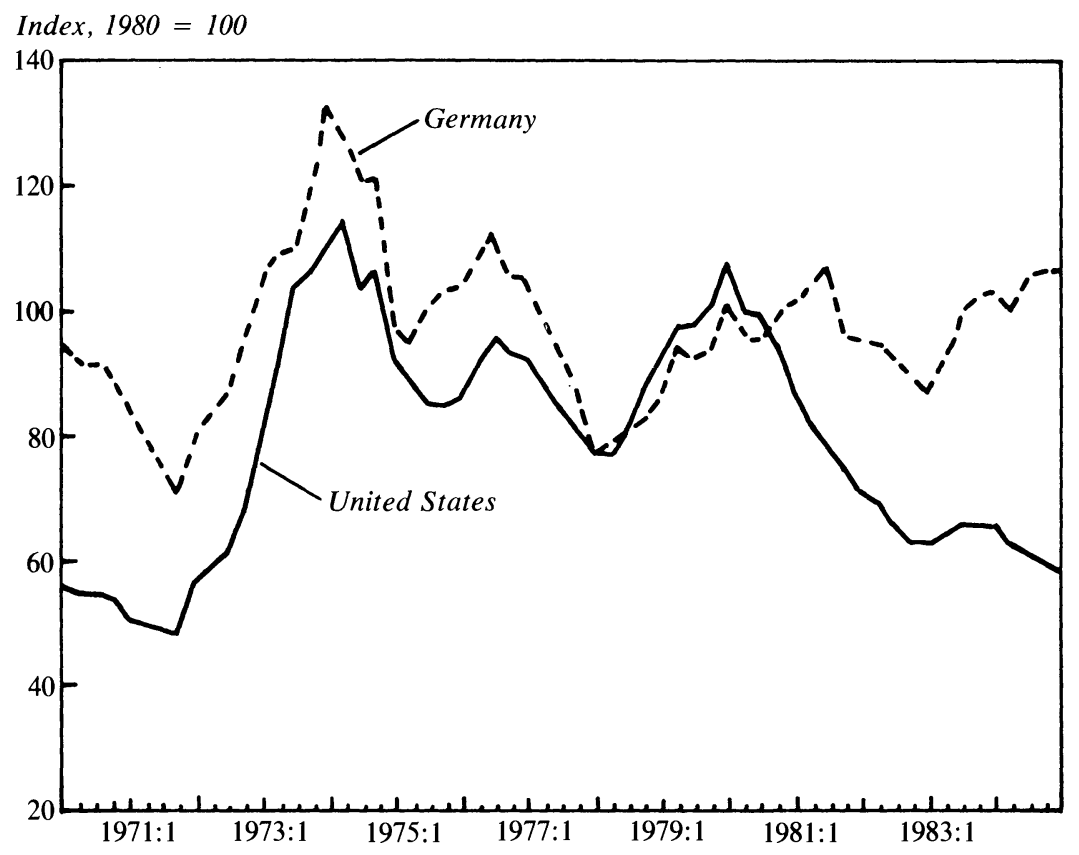

Sources: Same as figure 3 .

a. The real price of commodities here is expressed in terms of the respective countries' GNP deflator.

where $\eta$ and $\eta^{*}$ are the domestic and foreign price elasticities of commodity demand and $\beta$ and $\beta^{*}$ are the shares of the home country and the rest of the world in total demand. The elasticity of equilibrium price in terms of the U.S. deflator therefore must be a fraction. With equal demand elasticities, the elasticity reduces to the foreign share in world demand. ${ }^{13}$

This effect has nothing to do with commodities being priced in dollars. It is simply an implication of a flexible price model for commodities combined with an assumed change in the real exchange rate. Figure 7 shows striking evidence of the divergent movements of the real price of

13. The equilibrium price behaves as if commodities were priced in terms of a currency basket. See William H. Branson and Louka T. Katseli, "Currency Baskets and Real Effective Exchange Rates," in Mark Gersovitz and others, eds., The Theory and Experience of Economic Development (George Allen \& Unwin, 1982), pp. 194-214. 
Table 9. The Determinants of the Real Commodity Price, United States, 1970:2-1985:1 ${ }^{\mathrm{a}}$

\begin{tabular}{|c|c|c|c|c|c|}
\hline \multirow[b]{2}{*}{ Constant } & \multirow{2}{*}{$\begin{array}{l}\text { Real } \\
\text { exchange } \\
\text { rate }\end{array}$} & \multirow{2}{*}{$\begin{array}{c}\text { World } \\
\text { industrial } \\
\text { production }\end{array}$} & \multirow{2}{*}{$\begin{array}{c}\text { Real } \\
\text { interest } \\
\text { rate }\end{array}$} & \multicolumn{2}{|c|}{ Summary statistic } \\
\hline & & & & $R^{2}$ & $\begin{array}{l}\text { Durbin- } \\
\text { Watson }\end{array}$ \\
\hline-1.65 & $\begin{array}{c}-1.58 \\
(-4.56)\end{array}$ & $\begin{array}{c}2.25 \\
(4.55)\end{array}$ & $\ldots$ & 0.53 & 2.07 \\
\hline-1.67 & $\begin{array}{c}-1.55 \\
(-4.64)\end{array}$ & $\begin{array}{c}2.27 \\
(4.74)\end{array}$ & $\begin{array}{c}-0.24 \\
(-2.21)\end{array}$ & 0.56 & 2.03 \\
\hline
\end{tabular}

a. The dependent variable is real nonoil commodity price. It is measured as the Economist dollar index of commodities deflated by the U.S. GNP deflator. Industrial production is measured by the IMF index of industrial production in industrial countries. The real interest rate is measured as the U.S. medium-term bond yield less an inflation forecast derived from a first order autoregressive inflation model. The real exchange rate and industrial activity were entered as distributed lags. Numbers in parentheses are $t$-statistics.

commodities in terms of domestic and foreign deflators. The figure shows the real price of materials in terms of the U.S. and German deflator. Since 1980 the real commodity price has declined for the United States by more than 40 percent and increased for Germany by 14 percent. The discrepancy - a decline of the U.S. real commodity price and an increase abroad-is an interesting issue for which equation 7 already has an answer. Empirical results are offered in table 9.

The model was tested with quarterly data for the period 1970:21985:1. The real price of commodities in terms of the U.S. deflator was regressed on a distributed lag of the real dollar exchange rate and on world industrial production. The regression is run on the logs of the variables in first differences.

In the first equation in table 9, both industrial production and the real exchange rate appear as significant determinants of changes in the real commodity price. A percentage point growth in the OECD countries' level of industrial production raises real commodity prices by 2.25 percent. A percentage point real dollar appreciation reduces real commodity prices by 1.5 percentage points. The real exchange rate coefficient has the anticipated sign, but the effect is far larger than the model predicts. The prediction is that the coefficient should be a negative fraction, perhaps -0.5 and certainly not -1.5 .

A possible explanation is that the measure of the real exchange rate that is used in the estimates is very heavily weighted toward Japan and Canada, since it is trade-weighted and thus shows much less movement than the true variable corresponding to the two-region aggregation of equation 5 above. But it turns out that using a real exchange rate built 
with GDP weights rather than trade weights generates very similar results.

One alternative argument recognizes the possibility that on the supply side commodity extraction and storage costs are governed by the real interest rate. In this case, a rise in the real interest rate will lead to a reduction in the equilibrium real price. That effect is added in the second equation in table 9. The real interest rate is generated as the mediumterm U.S. bond yield less a two-year-ahead forecast of the inflation rate of industrial countries' export prices generated from a rolling first order autoregression model. A rise in the real interest rate does indeed lead to a reduction in the real commodity price. But the introduction of the real interest rate does not modify the coefficient of the real exchange rate and hence leaves the puzzle.

A more promising alternative is to consider the supply side. It can be shown that under certain conditions the supply side can, indeed, lead to the more than proportionate effect we find. What is required is the following: that supply be responsive to the real price of commodities in LDCs and that the real currency exchange rate of the LDCs relative to the dollar move proportionately more than that of the industrialized countries. Thus if the dollar appreciates relative to the currencies of industrialized countries, it appreciates even more relative to those of the LDCs. Under these conditions it is possible to obtain an elasticity of the real price with respect to the real dollar exchange rate that exceeds unity in absolute value.$^{14}$ In terms of figure 6 , the argument implies a positively sloped supply schedule that shifts downward with a dollar appreciation by enough to offset the downward shift of the world demand schedule.

To summarize, the welfare analysis so far shows that growth in industrialized countries exerts a strong effect on LDC terms of trade. In addition, because the prices of commodities in terms of the U.S. deflator overreact to the U.S. real exchange rate, the real commodity price in terms of industrial countries' exports tends to fall with a strengthening of the dollar. The implication is that LDCs have an interest not only in

14. Let $S=S\left(P_{c} / e^{\prime} P^{\prime}\right)$, where $P^{\prime}$ is the GNP deflator in producing countries and $e^{\prime}$ the dollar price of their currencies. We can write $P_{c} / e^{\prime} P^{\prime}=\left(P_{c} / P\right)\left(P / e^{\prime} P^{\prime}\right)$. Let d $\ln \left(P^{*} / e^{\prime} P^{\prime}\right)$ $=(1+\kappa) \mathrm{d} \ln \left(P / e P^{*}\right)$. With $\epsilon$ denoting the supply elasticity, the elasticity of the real commodity price is: $\partial \ln \left(P_{c} / P\right) / \partial \ln \left(P / e P^{*}\right)=-\left[\beta^{*} \eta^{*}+\epsilon(1+\kappa)\right] /\left(\epsilon+\beta \eta+\beta^{*} \eta^{*}\right)$. The elasticity is larger than unity in absolute value if $\kappa \epsilon>\beta \eta$. There is no a priori reason for excluding this possibility. 
growth in industrialized countries, but also in the distribution of growth between areas and in the policy mix, both of which affect the value of the dollar and hence the terms of trade. Other things being equal, a strengthening of the dollar will worsen the terms of trade of net commodity exporters and hence reduce their welfare. For net commodity importers, the reverse pattern holds.

\section{EXPORT VOLUME}

The welfare analysis assigns a role to LDC export growth only in the context of well-specified distortions that either make resources not fungible or associate excess benefits with the production of exportables such as scale economies or monopoly profits. This potential welfare role warrants a look at the determinants of export volume. There is certainly a link between LDC export volume and economic activity in industrial countries, but precise estimates are impossible, because the available data do not give a robust answer as to the elasticity of the link.

A look at the data on OECD growth and LDC export growth shown in table 10 makes the complexity of the link clear. The table shows that growth in the industrialized countries slowed during the 1970s, a period during which export volumes from LDCs actually accelerated. The table also shows that while export growth from Asia during the 1960s ran far ahead of that from Latin America, the gap widened still further during the 1970s. Thus, it appears that factors other than industrial countries' growth are important determinants of LDC export growth.

Looking at OECD imports from another direction, the Bergsten-Cline regression (frequently used for back-of-the-envelope LDC export growth predictions) explains the import volume growth of the OECD countries, including intra-OECD trade, by the growth rate of their own GDP. ${ }^{15}$ The related regression shown in equation 9 uses annual data for the period 1960-83 (numbers in parentheses are $t$ - statistics).

$$
\begin{gathered}
\text { OECD import growth }=-3.21+2.55 \text { OECD growth } \\
(-2.52) \quad(8.39) \\
R^{2}=0.75 ; \text { Durbin-Watson }=2.19 .
\end{gathered}
$$

15. See William R. Cline, International Debt: Systemic Risk and Policy Response (MIT Press, 1984), p. 241; and Cline, ed., Trade Policy in the 1980s (MIT Press, 1983), p. 74. 
Table 10. Average Annual Growth Rates, Selected Periods, 1960-83 Percent

\begin{tabular}{|c|c|c|c|c|c|c|}
\hline \multirow[b]{2}{*}{ Period } & \multicolumn{3}{|c|}{ Industrial country growth } & \multicolumn{3}{|c|}{ Nonoil LDC export volume growth } \\
\hline & $G D P$ & $\begin{array}{l}\text { Industrial } \\
\text { production }\end{array}$ & $\begin{array}{l}\text { Import } \\
\text { volume }\end{array}$ & $\begin{array}{c}\text { All } \\
\text { nonoil } \\
\text { LDCs }\end{array}$ & Asia & $\begin{array}{c}\text { Western } \\
\text { hemisphere }\end{array}$ \\
\hline $1960-83$ & 3.7 & 4.3 & 6.4 & 6.1 & $8.6^{\mathrm{a}}$ & 5.5 \\
\hline $1970-83$ & 2.8 & 2.6 & 4.2 & 7.4 & 10.4 & 6.1 \\
\hline
\end{tabular}

Source: IMF, International Financial Statistics.

a. $1964-83$

The elasticity estimate is slightly lower than the original BergstenCline 3:1 link, but the regression clearly confirms their finding. Of course, the data refer to total import growth from all sources, of which imports from nonoil LDCs is only one. The distinction is important, since the exports of nonoil LDCs account for only 17 percent of total industrial countries' imports. The next step is to move from total OECD import volume to the export volume of LDCs.

Table 11 shows a regression for export volume growth of all nonoil LDCs, estimated with annual data for the 1960-83 period. The first two equations refer to the growth rate of export volume for all nonoil developing countries, while the last two pertain to major LDC exporters of manufactures. The explanatory variables are the growth rate of industrial countries (OECD growth) and the percentage change in the relative price or competitiveness of this group's exports (COMP). The relative price is measured as the LDC export unit value deflated by the export unit value of industrial countries. The 1970s dummy assumes a value of zero in 1961-71 and a value of unity in the remainder of the sample. It stands for increased LDC trade orientation, regional diversification, and OPEC's emergence as a major market.

The table shows that the elasticity estimate of LDC export growth with respect to OECD growth cannot be pinned down. Once the 1970s dummy is entered, the cyclical elasticity increases strongly. Moreover, when lagged OECD growth is included (results not shown in the table), the coefficient of that variable is always negative, though not always significant.

The instability of the estimates in response to even slight changes of the specification reflects the fact that the left-hand side variable shows a variation between -12 and +30 percent for the export growth of all 
Table 11. The Determinants of Nonoil LDC Export Growth, 1960-83

\begin{tabular}{|c|c|c|c|c|c|}
\hline \multirow[b]{2}{*}{ Constant } & \multirow[b]{2}{*}{ COMP } & \multirow[b]{2}{*}{$\begin{array}{l}\text { OECD } \\
\text { growth }\end{array}$} & \multirow[b]{2}{*}{$\begin{array}{c}\text { 1970s } \\
\text { dummy }\end{array}$} & \multicolumn{2}{|c|}{ Summary statistic } \\
\hline & & & & $R^{2}$ & $\begin{array}{l}\text { Durbin- } \\
\text { Watson }\end{array}$ \\
\hline \multicolumn{6}{|c|}{ All nonoil $L D C s$} \\
\hline-0.31 & $\begin{array}{c}-0.47 \\
(-2.64)\end{array}$ & $\begin{array}{c}1.74 \\
(2.49)\end{array}$ & . . & 0.39 & 1.95 \\
\hline-10.3 & $\begin{array}{c}-0.50 \\
(-3.62)\end{array}$ & $\begin{array}{c}3.19 \\
(4.84)\end{array}$ & $\begin{array}{c}9.63 \\
(3.81)\end{array}$ & 0.63 & 2.30 \\
\hline \multicolumn{6}{|c|}{ LDC major exporters of manufactures } \\
\hline 1.09 & $\begin{array}{c}-1.24 \\
(-3.22)\end{array}$ & $\begin{array}{c}2.67 \\
(2.36)\end{array}$ & $\ldots$ & 0.41 & 1.85 \\
\hline-13.0 & $\begin{array}{c}-1.15 \\
(-3.50)\end{array}$ & $\begin{array}{c}4.74 \\
(3.00)\end{array}$ & $\begin{array}{l}13.41 \\
(2.96)\end{array}$ & 0.58 & 1.92 \\
\hline
\end{tabular}

a. The dependent variable is export volume growth in nonoil LDCs. COMP is the percent change in the relative price of industrial countries' exports. Relative price is the LDCs' export unit value index divided by the same index for the industrial countries. The dummy variable is zero in 1961-71 and one in the rest of the sample. Numbers in parentheses are $t$-statistics.

nonoil LDCs and -11 to +53 percent for major manufactures exporters, variations which are importantly influenced by one event, the 1974-76 business cycle. With a larger set of data it would be important to try and separate out short-term inventory-related responses and responses to changes in medium-term growth rates. At this stage there is certainly no firm finding, here or in the literature, regarding the elasticity. In addition there are domestic variables not captured in the constant. Recession in LDCs, especially, would tend to promote growth of exports. ${ }^{16}$

The uncertainty about the size of the income elasticity is troublesome, because OECD growth is invariably the central feature of any assessment

16. Further evidence is reviewed by Goldstein and Khan, who distinguish between manufactures and other commodities and by subgroup of exporting countries. Their estimates of the elasticity in the 1973-80 period are in some cases as high as 2.3 . The high elasticities for manufacturing exporters are also identified in a study by Bond, who disaggregates trade flows by import market using annual data for the period 1967-81. In that study the cyclical elasticity of manufacturing exporters with respect to GDP in industrial countries and OPEC are, respectively, 2.91 and 1.88. Here, too, the question arises whether GDP growth in part serves as a proxy for structural change on the demand or supply side. See Morris Goldstein and Mohsin S. Khan, "Effects of Slowdown in Industrial Countries on Growth in Non-Oil Developing Countries," Occasional Paper 12 (IMF, August 1982); $: \rightarrow$ Marian E. Bond, "Export Demand and Supply for Groups of Non-oil Developing Countries," IMF Staff Papers, vol. 32 (March 1985), pp. 56-77. Equations estimated using data from the IFS tapes show very poor results, but come up consistently with elasticities close to unity or even less. 
of the future of the debt crisis. The results in table 11 can be interpreted as suggesting that elasticities are high and perhaps very high. But the instability of the estimates is so large that these high estimates are to a large extent an artifact of the 1974-76 period. LDCs might be important marginal suppliers, with significant short-run income elasticities of demand for their goods, enhanced by inventory accumulation effects, but with a much smaller medium-term response.

The regressions show a sizable effect of competitiveness on export volume. Moreover, that effect is stable across alternative specifications of the equations. As is to be expected, the elasticity is larger for major exporters of manufactures. The significant response of export volume to competitiveness of course points to adjustment programs that involve real depreciation as an important element.

Purchasing Power of Exports. The purchasing power of exports is defined as export revenue deflated by import prices. The determinant of the purchasing power of exports should be OECD growth that affects volume as well as the terms of trade. An estimated equation using annual data for the purchasing power of exports of all nonoil LDCs is reported in table 12. The explanatory variables are OECD growth, changes in competitiveness one year lagged, and the 1970s dummy already used above.

The interesting point about these regressions is the combined termsof-trade and volume effect. The elasticity estimate of 2.5-3 suggests that the high volume elasticities in the regressions might overstate the OECD impact. William Cline and Carlos Diaz-Alejandro have found as an additional explanatory variable a role for the lagged change in growth. ${ }^{17}$ That effect does come out in the data, but it is difficult to understand it in economic terms. It might well be associated with the 1974-76 period.

\section{EXTERNAL DEBT AND INTEREST RATES}

A large part of LDC debt is bank debt, denominated in dollars with floating-rate debt service, geared primarily to LIBOR but also in some cases to the U.S. prime rate. Developments in short-term interest rates in the United States are therefore of immediate relevance for debtor countries. Although the distinction between gross and net debt is

17. See Cline, International Debt; and Carlos F. Diaz-Alejandro, "Latin American Debt: I Don't Think We Are in Kansas Anymore,’ BPEA, 2:1984, pp. 335-89. 
Table 12. Purchasing Power of Exports of Nonoil LDCs, 1961-83a

\begin{tabular}{cccccccc}
\hline & & & & \multicolumn{3}{c}{ Summary statistic } \\
\cline { 5 - 7 } Constant & $\begin{array}{c}\text { Lagged } \\
\text { COMP }\end{array}$ & $\begin{array}{c}\text { OECD } \\
\text { growth }\end{array}$ & $\begin{array}{c}1970 \mathrm{~s} \\
\text { dummy }\end{array}$ & Rho & $R^{2}$ & $\begin{array}{c}\text { Durbin- } \\
\text { Watson }\end{array}$ \\
\hline-4.18 & $\ldots$ & 2.63 & $\ldots$ & 0.29 & 0.48 & 1.96 \\
& & $(4.45)$ & & & & \\
-8.56 & $\ldots$ & 3.04 & 5.77 & $\ldots$ & 0.63 & 1.94 \\
& & $(6.10)$ & $(2.96)$ & & & \\
-5.94 & -0.44 & 2.44 & 4.97 & $\ldots$ & 0.73 & 2.11 \\
& $(-2.87)$ & $(5.14)$ & $(2.95)$ & & & \\
\hline
\end{tabular}

a. The dependent variable is growth in purchasing power of exports in nonoil LDCs, defined as export revenue deflated by import prices. See note to table 11 for definition of the variables. Numbers in parentheses are $t$-statistics.

neglected here, it is worth noting, because LDCs have, in some cases, large external assets. In fact, some major borrowers incurred their debts in the very act of financing capital flight by domestic residents. Hence, at least in accounting terms, the external debt is matched by holdings of external assets. However, these private assets are beyond the control of the authorities, making the gross external debt the relevant measure. ${ }^{18}$

There are no solid data on the currency composition of debts. The OECD estimates that the share of dollar debt in total debt is about 50 percent in the case of long-term liabilities and about 70 percent for shortterm debts. ${ }^{19}$ This high dollar concentration plays an important role in the context of a policy mix that involves high U.S. interest rates and dollar appreciation.

Spreads. The debt service of LDCs is linked to interest rates in the world capital market via LIBOR. The basic interest rate charged on debt is LIBOR plus a "country" spread. In 1983 average spreads on new credits were 180 basis points. In recent reschedulings these spreads declined to 100 basis points. But the interest rate also includes a second spread, that between LIBOR and the "risk-free" interest rate, say the U.S. T-bill rate. That average spread in the $1974-84$ period was 187 basis

18. See Rudiger Dornbusch, "Budget Deficits, Disequilibrium Exchange Rates and External Debt," in Gordon W. Smith and John T. Cuddington, eds., International Debt and the Developing Countries (World Bank, 1984), pp. 213-35, and The World Bank, World Development Report, 1985.

19. See Organization for Economic Cooperation and Development, External Debt of Developing Countries, 1983 Survey (OECD, 1984), and The World Bank, World Development Report, 1985. 
points, but it fell as low as 75 basis points in 1984. This "banking" spread reflects costs of bank intermediation and the risk premium banks have to pay in funding their own lending.

Equation 10 explains the banking spread in terms of the level of the T-bill rate, the log of the real price of oil, and a dummy for the Herstatt episode in 1974, when funds to the Eurodollar market dried up because of uncertainty about legal commitments of parent banks. The Herstatt dummy assumes a value of unity for 1974:2 to 1974:4 and zero elsewhere. The real oil price appears as a proxy for the effect of increased placements by oil producers in the Eurodollar market.

$$
\begin{aligned}
& \text { Spread }=2.68+0.25 \text { T-bill }-0.71 \text { Oil price } \\
& \text { (4.65) (6.14) (-4.03) } \\
& +1.86 \text { Herstatt dummy } \\
& \text { (4.92) } \\
& R^{2}=0.67 ; \text { Durbin-Watson }=2.0 .
\end{aligned}
$$

The regression explains a significant part of the variation in the spread, and each of the explanatory variables is highly significant. Most interesting is the level of the T-bill rate. A 4 percentage point rise in the level of the T-bill rate raises the spread by a full percentage point.

The Real Interest Rate. For welfare questions, the real interest rate, not the nominal rate, is significant. Figure 8 shows the real rate of interest on LDC debts, measured as the six-month lagged LIBOR adjusted by the three-month forward rate of inflation of export unit values of nonoil LDCs. The outstanding periods are 1972-73 and 1976, with negative real rates of up to 33 percent, and $1980-82$, with positive real rates reaching 47 percent.

Measuring the real interest rate poses two separate issues. The first is whether it is meaningful to look at short-term real interest rates in assessing debt burdens. To the extent that real rates are high because of a transitory decline in prices that is subsequently reversed, long-term real rates would average to much smaller numbers, and a period such as 1973 or 1981 might exaggerate events. But there is really no serious reason why capital gains or losses-the revaluation of the real value of debts-should not be carried along and treated as a component of real interest. The procedure is technically correct and eliminates guessing about normal prices. 
Figure 8. The Real Interest Rate of Nonoil LDCs, 1971:1-1984:3

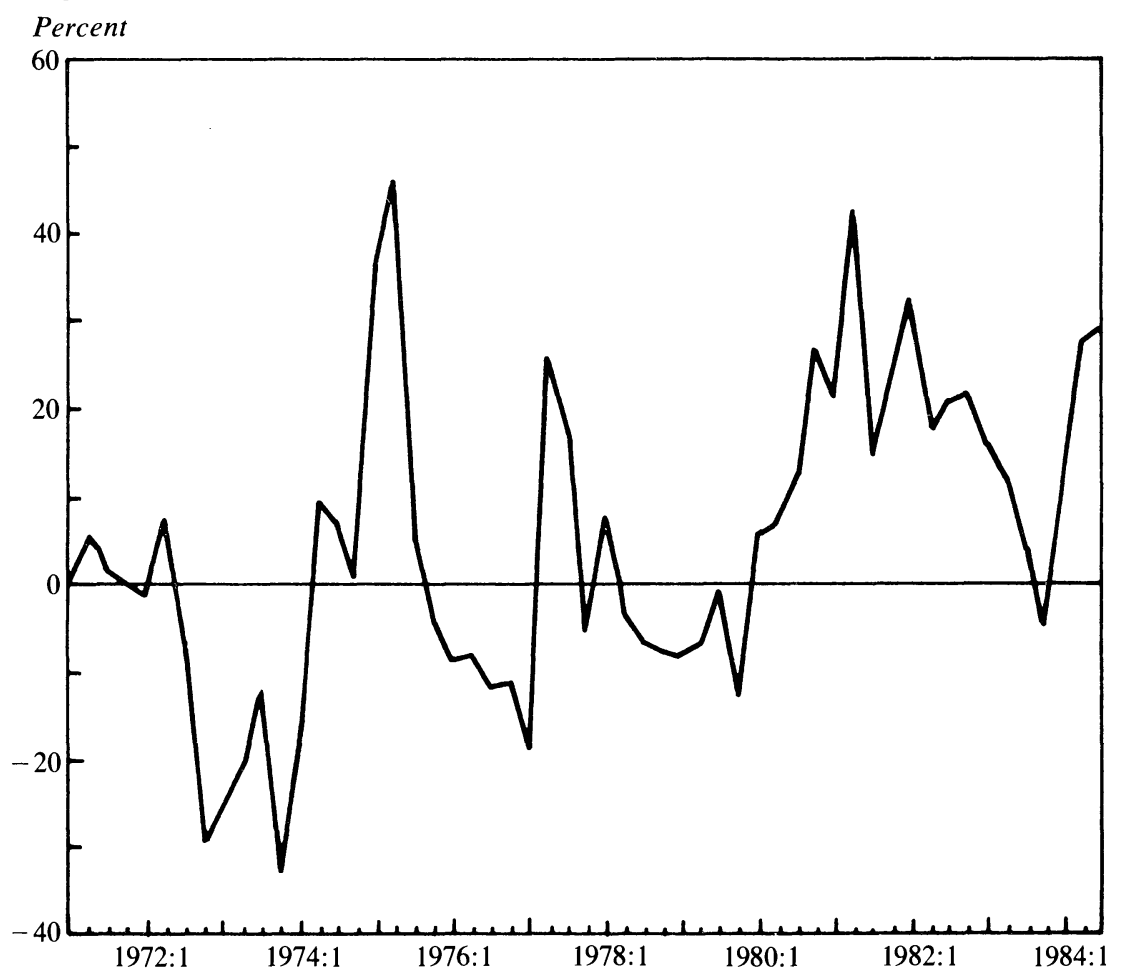

Source: IMF, International Financial Statistics.

a. The real rate is measured as the six-month lagged LIBOR adjusted with the three-month forward rate of inflation of export unit values of nonoil LDCs.

The second issue concerns the appropriate deflator-export prices, import prices, some mix of the two, U.S. prices, or debtor GDP deflators or consumer price indexes. Theory here leaves no question: consumer and producer decisions are geared to the consumption rate of interest in terms of the CPI and to the rate of interest on investment. ${ }^{20}$ Welfare questions can be consistently answered with the expression developed in the appendix. The choice of numeraire for measuring welfare effects in no way implies that changes in other prices do not have welfare effects if they change implicit real interest rates. ${ }^{21}$

20. See Rudiger Dornbusch, "Real Interest Rates, Home Goods, and Optimal External Borrowing," Journal of Political Economy, vol. 91 (February 1983), pp. 141-53.

21. Specifically, let all future import prices rise by $\sigma$ percent, with no changes in export prices. In equation 16 of the appendix we then have: $\Delta W=-\Sigma M_{i}^{t+1} p_{i}^{t+1} \sigma$. But from the 


\section{The Implications of Alternative OECD Policy Mixes}

Debtor nonoil LDCs, as the preceding analysis shows, have a common interest in some combination of strong OECD growth, low real interest rates, and a weak dollar-a reenactment of 1972-74. The precise effects of OECD growth, interest rates, and the dollar, however, differ from country to country, depending on the trade and debt structure of individual LDCs.

A combination of, say, 1.5 extra points of OECD growth, 2 percentage points higher LIBOR rates, and a 10 percent dollar appreciation could mean a net financial benefit to one LDC, a net loss to another. The higher an LDC's bank debt is relative to exports, and the larger its concentration in commodity exports, the less likely that country is to gain. But if the same OECD growth came because of reduced interest rates and were accompanied by a decline in the dollar, commodity exporters and debtors alike would gain. Under certain circumstances, even lower OECD growth can help. A recession in the industrialized nations that led to a cyclical decline in interest rates might benefit a large debtor because the lower interest rates could more than offset the disadvantage of reduced growth.

There are two possible approaches to the discussion of linkages between OECD macroeconomics and LDC performance. One evaluates disturbances from the LDC welfare perspective. The other, a cash-flow approach, focuses on the sustainability of debts. It has no normative implications but rather asks whether LDC debts over time become better or poorer assets. It views a declining debt-export ratio as an improving course of events. The evaluation of linkages in the preceding section clearly indicates important linkages between events at the center and LDC debt problems via terms of trade, export volume, and interest rates. The cash-flow debt model organizes these factors to analyze debt dynamics.

budget constraint in equation 14a we can substitute to obtain: $\Delta W=\sigma\left(K-R^{*} X^{t+1}\right)$, where $K$ denotes initial debt plus first period borrowing. Hence a rise in import prices at constant nominal interest rates raises welfare in proportion to initial debt plus borrowing. In addition, there is, of course, the adverse terms-of-trade effect, $-R^{*} X^{t+1} \sigma$, which has an offsetting effect on welfare. 
THE CASH-FLOW MODEL OF DEBT DYNAMICS

Official policy in the industrialized countries, and perhaps mostly in the United States, is to restore the quality of LDC debts. The necessity of keeping debts "productive" is seen as an essential organizing principle of international relations and adjustment programs in LDCs. The belief is that the sheer passage of time, together with necessary and desirable adjustments in LDCs, will produce a path of current accounts, debt accumulation, and export revenues that implies a declining ratio of debt to exports.

Cline pioneered this approach and created a framework of analysis that was to the debt problem what penicillin is to public health. The view was that within a few years, given dollar depreciation, moderate interest rates, and sustained OECD growth, debt-export ratios even of major debtors would fall back to the levels of the early 1970s. Moreover, that correction could be achieved under conditions of growth in the debtor countries. ${ }^{22}$

The analysis lends plausibility to the idea that international banking has finally come to grips with the perennial problem of LCD defaults. The essential step was to recognize that liquidity problems, not the longrun fundamentals, are what gives rise to default. Hence, the IMF was taken down from the shelves, dusted off, and given a new life (far away from multilateral surveillance applied to U.S. fiscal policy) as liquidity and adjustment manager.

The model of debt dynamics recognizes that the evolution of the debtexport ratio is governed by two determinants: the nominal interest rate on debt relative to the growth rate of export revenue, $i^{*}-\lambda$, with $\lambda$ the growth rate of export revenue, and the noninterest current account surplus as a fraction of exports, $x$. With the debt-export ratio denoted by $d$, the basic equation for the rate of change of the debt-export ratio is:

$$
\frac{\dot{d}}{d}=\left(i^{*}-\lambda\right)-\frac{x}{d}
$$

22. See Cline, International Debt , and "International Debt: From Crisis to Recovery?" American Economic Review, vol. 75 (May 1985), pp. 185-90. 
Figure 9. Debt Dynamics

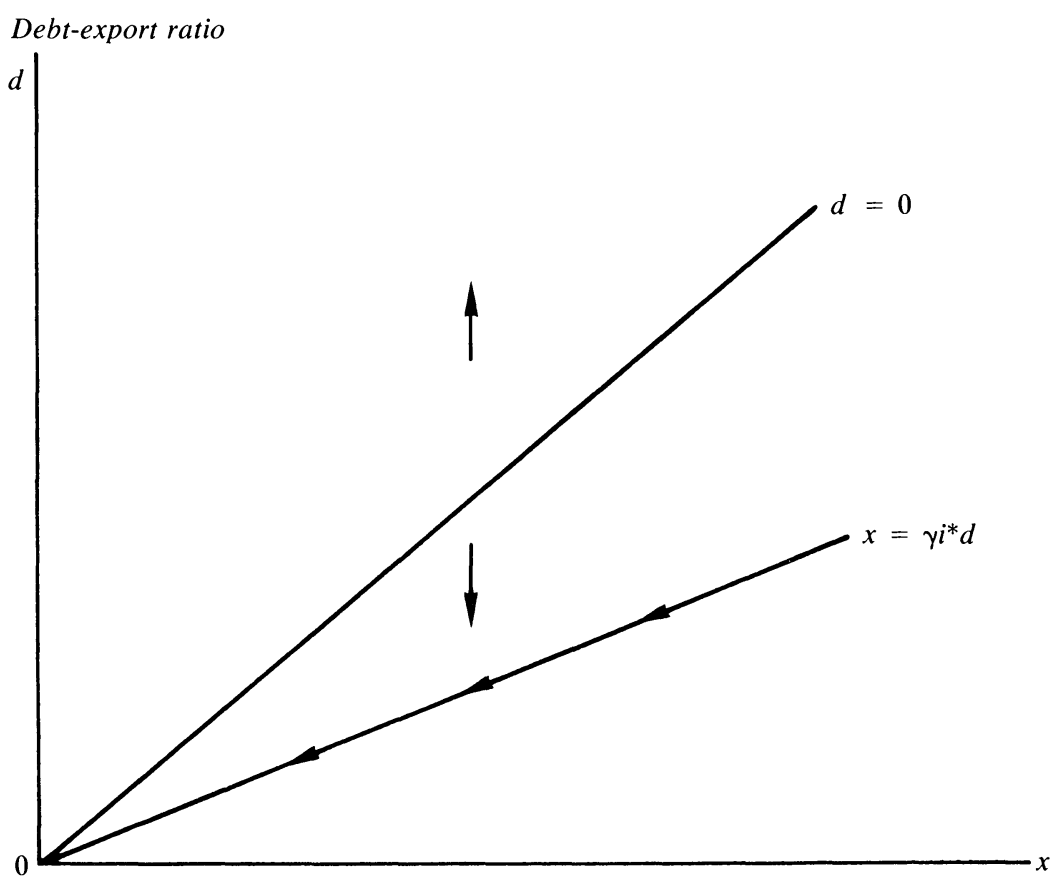

Ratio of noninterest surplus in current account to exports

The equation states that the debt-export ratio falls if the rate of interest falls short of the growth rate of export revenue, $i^{*}-\lambda<0$. Note that the relevant interest rate here is the effective rate, which is the weighted average across all kinds of debt, ranging across creditors and currency denominations. Even if that condition fails to hold, the debt-export ratio can still be declining provided the debtor country runs a sufficiently large noninterest current account surplus, which will be used to pay a fraction, $\alpha$, of debt service:

$$
x=\alpha i^{*} d
$$

Any part of the interest bill that is not paid by the noninterest current account surplus is automatically financed by new borrowing. Figure 9 shows the case where the interest rate exceeds the growth rate of export earnings. The debt process is still stable, converging to zero debt, 
Table 13. The Determinants of Debt Accumulation, 1970-85

Annual average, in percent

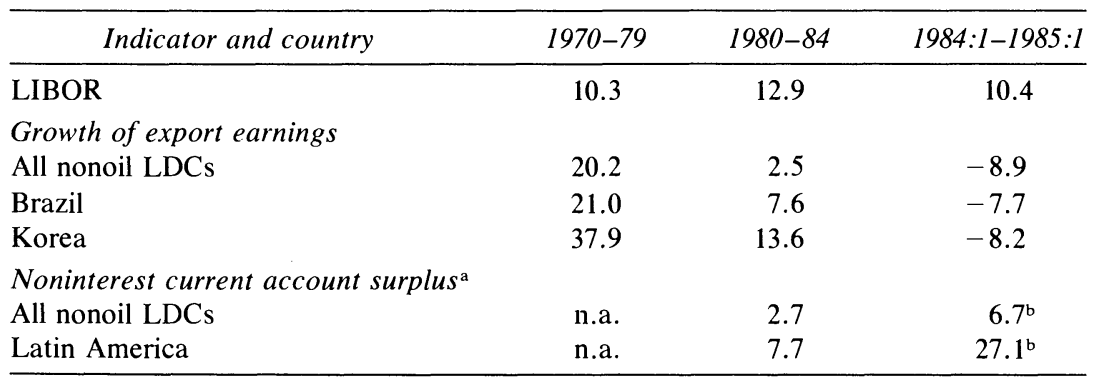

Sources: IMF, International Financial Statistics, and World Economic Outlook, 1985.

n.a. Not available.

a. Percentage of exports of goods and services.

b. 1984-85.

provided $\lambda>i^{*}(1-\alpha)$. Of course, if export revenue falls, more than the whole interest bill must be paid in order to avoid growth in the debtexport ratio.

Table 13 shows data for LIBOR, the growth rates of export earnings, and noninterest current accounts. In the period 1970-79 the growth rate of exports substantially exceeded interest rates, leaving ample room for noninterest deficits. The LDCs could receive resource transfers without a deterioration in their external creditworthiness as measured by the debt-export ratio. In fact, any country that ran a deficit, even one as large as its interest payments, would have experienced a dramatic reduction in its debt-export ratio.

As the table shows, during the period 1980-84 the climate became problematic for debtors with low export growth. Unless they made adjustments, as did Korea, their debt-export ratio in fact would deteriorate massively. For Latin America, the period was catastrophic. Whatever useful purpose external borrowing had served in the early 1970s, in 1979-82 it primarily financed capital flight and poor public finance. Of course, if the 1984-85 experience of falling export revenue continues for any length of time, it opens a totally new game: with declining revenues the joy of debt service falters even for the eager. The question is whether OECD macroeconomic developments can be expected now to make a decisive contribution to the solution of the debt problem or whether, just as in 1983-85, most of the work must be done by involuntary debt service on the part of debtor LDCs. 


\section{SCENARIOS}

From the point of view of industrialized countries, the common policy objectives are to sustain growth under conditions of low inflation and continuing correction of budget deficits. Objectives differ with respect to the dollar. The United States would prefer, inflation aside, a weaker dollar so as to achieve stronger recovery in manufacturing and improved conditions in agriculture. For Europe, troubled by record unemployment and a real wage already thought too high, a depreciating dollar would present a difficult problem. In a longer term perspective, the central problem of industrialized countries and the world economy is, however, the level of real interest rates. Unless real rates decline, budget correction seems unlikely or at least extremely costly. In the meantime, high real rates impair capacity expansion and hence the longer term performance of the industrialized countries with respect to growth, price stability, and stability of finance.

A case has been made for a monetary-fiscal policy mix that involves a transitory European fiscal expansion, a long-term fiscal tightening in the United States, and an accommodating monetary policy. ${ }^{23}$ That continues to be the "first-best" recommendation. It is first-best in that it would ensure a continuing recovery together with a declining dollar. The accommodating monetary policy would even solve the real interest rate problem, or at least not worsen it, although at the risk of some increase in inflation. The package would not solve the LDC debt problem by the stroke of a pen, but it would help via dollar depreciation and continuing growth. For the moment, however, there appears to be no inclination in Europe to turn toward coordinated fiscal expansion, even of a transitory nature. World attention has focused on the U.S. budget deficits, and it is firmly believed that cutting the deficits will remedy many if not all of the problems of the world economy. This is very doubtful.

23. See Olivier Blanchard and Rudiger Dornbusch, "U.S. Deficits, the Dollar and Europe,"' Banca Nazionale del Lavoro, Quarterly Review, no. 148 (March 1984), pp. 89113; R. Layard and others, "The Case for Unsustainable Growth," CEPS Discussion Papers (Brussels: Center for European Policy, April 1984); Blanchard and others, "Employment and Growth: A Two-Handed Approach," CEPS Discussion Papers (Brussels: Center for European Policy Studies, May 1985); and Rudiger Dornbusch, " Sound Currency and Full Employment'(London: The Employment Institute, May 1985). 
The position of the United States, and hence the LDCs, is uncomfortable. The U.S. monetary-fiscal mix can be changed only at the cost of provoking some renewed inflation or recession. A shift toward tight fiscal policy and lower real interest rates can, of course, be brought about by raising taxes and expanding the real money stock. Moreover, the change can be made in a manner that sustains the level and rate of expansion of total OECD demand. What cannot easily be done is to avoid the dollar depreciation that would almost inevitably accompany such a change of the mix. And if the dollar depreciation were to occur on a significant scale, it could easily become the source of an acceleration of inflation.

There is an obvious difficulty in reconciling the interests of LDCs and the industrial countries. The United States had through 1983-84 the best of all worlds: strong recovery and growth without significant acceleration of inflation. The growth could take place, because of fiscal expansion, despite high interest rates. But the high interest rates served as a protection against a collapse of the exchange rate and hence inflationary pressure from importables. It might seem unreasonable to suggest that the dollar be kept overvalued, until further notice, simply to delay the day of reckoning with respect to U.S. inflation. It might seem equally unreasonable to enact wage controls merely to avoid an extra 2 or 3 percent inflation stemming from the impact of an exchange rate collapse on wages. It might, however, be entirely reasonable to pursue first-best policies in the industrial countries in the belief that in the longer run LDCs can benefit only from the macroeconomic stability of the advanced countries. To do this, one would correct U.S. fiscal policies over the next few years in a credible fashion, pursue at least a transitory fiscal expansion in Europe, and make sure that the dollar comes down gently and in an undisruptive manner. This is the soft-landing option that may have been in the making during the past few months.

The immediate concerns of the LDCs are liquidating debt and raising real commodity prices. In the short run, the OECD policy that would give the greatest relief would be one featuring the most reckless spending and money printing imaginable. Policy options that emphasize soft landing are at best in the LDCs' interest only when one looks far ahead and argues that this is the only avenue for securing sustained growth.

While OECD policies are not governed by the interests of LDCs, the outlook for OECD macroeconomics does not suggest a decisive deteri- 
oration in the cash-flow debt dynamics. There is no expectation of a continuing decline in export revenues or of increasing interest rate levels. Some dollar depreciation and moderate growth and inflation allow an outlook of $10-15$ percent growth in export earnings, a rate, for most countries, greater than the effective interest rate. But that outlook makes it clear that neither dollar collapse nor high, sustained growth can be expected. Nor, on the other hand, should one expect protracted recession or sharp increases in interest rates.

In sum the scenario for OECD countries provides a neutral setting for any LDC that does not, as yet, have debt difficulties. Problem debtors should not expect rapid relief. For Latin debtors, most of the relief must come from their domestic adjustment or a rewriting of the debt. OECD macroeconomics will in all likelihood do little to work down debt-export ratios. That must come from noninterest surpluses that the LDCs are trying to accumulate as part of the stabilization programs.

\section{Adjustment in the LDCs}

In 1946 the Foreign Bondholders Protective Council reported that of the outstanding publicly offered or guaranteed dollar bonds of Latin America, 53 percent were in default as to interest and sinking fund, 45 percent were receiving adjusted debt service, and only 2 percent were serviced in full. ${ }^{24}$ Such a situation has characterized much of the past 150 years. But in one crucial respect, the current experience is completely new. Today, developing countries are not receiving resource transfers to foster capital accumulation and growth in their standard of living. Instead, they are servicing their debts by transferring resources toward the creditors. Even more serious, the creditors are reluctant to receive debt service in the only way it can come, namely in kind, by LDC trade surpluses. Just as in the 1930s prior to massive LDC default, the creditors are erecting trade obstacles to debt service.

There is now a confusion of priorities: banks practice credit rationing, seeking a reduction in the debt-export ratio on a dramatically accelerated path that is entirely unwarranted by any consideration of debt stability. ${ }^{25}$

24. See Foreign Bondholders Protective Council, Inc., Report for Years 1946 to 1949 (New York, 1950), pp. 376-77.

25. See D. Cohen, "LDC Debt Service and Solvency," paper presented at the Economic Policy Conference, Paris, June 1985; and Mario Henrique Simonsen, "The 
The primary purpose is to reduce the cost of capital for banks and enhance bank balance sheets. LDCs may benefit from reductions in the cost of capital to banks, but surely not sufficiently to warrant the debt retirement strategy.

Debt service, as the German experience with reparations in the interwar period amply demonstrates, involves a transfer problem. The problem arises in three ways: how to raise the budget revenue for debt service in a noninflationary way, how to shift resources to the external sector so as to cut the budget and accumulate a trade surplus under conditions of high employment, and how to succeed in earning the foreign exchange with which to service the debt. At each step things can go badly wrong.

Among the particular circumstances influencing a nation's ability to service its external debt, four deserve special attention. The first is the burden of interest payments as measured by the ratio of interest payments to GDP. The second is the openness of the economy as measured by the ratio of exports to GDP. The remaining two are politics and the public sector budget. These circumstances determine for each nation both its welfare losses from an external disturbance and its macroeconomic performance upon being exposed to a shock. I now discuss each in turn, using the perspective of the three aspects of the transfer problem. Table 14 highlights two of the elements, the interest burden and the degree of openness.

\section{THE BUDGET PROBLEM}

The source of the budget problem is debt nationalization, which occurs when private sector debt is dumped into the budget in the course of the financial collapse of the banking system. This experience is peculiar to Latin America and is not common in Asia.

Governments that already have difficulties financing their fiscal expenditures are suddenly forced to marshal resources worth several percent of GDP. A tax increase is out of the question, because the burden would fall primarily on wage earners, not on capital, which effectively avoids taxation. Inflation, therefore, is the inevitable outcome, at least as long as the government finds no way to cut spending. But financing

Developing-Country Debt Problem," in Smith and Cuddington, eds., International Debt and the Developing Countries, pp. 101-26. 
Table 14. Structural Characteristics of LDCs, 1984

Percent of GDP

\begin{tabular}{lrccrr}
\hline \multicolumn{1}{c}{ Item } & Asia & Africa & America & Korea & Brazil \\
\hline Interest payments & 1.7 & 2.8 & 4.7 & 5.1 & 5.5 \\
Exports & 27.7 & 24.6 & 16.4 & 37.3 & 10.3 \\
\hline
\end{tabular}

Source: IMF, International Financial Statistics, and World Economic Outlook, 1985, and Morgan Guaranty.

debt service as large as a few percentage points of GDP with inflation means a dramatic increase in inflation.

The public, recognizing that the increased charge on the budget represents inflation and possibly asset taxation, turns to the foreign exchange market. Speculation against the currency, if there is capital mobility, will immediately lead to pressure on reserves and hence inevitably to a sharp depreciation of the currency, further increasing inflation. The problem is aggravated when an already precarious budget situation is worsened by reduced foreign exchange revenues as, for example, is the case in Mexico.

If exchange rate collapse is to be avoided, asset holders have to be compensated by sufficiently high rates of interest. In Brazil, Mexico, and Argentina, real interest rates range between 50 and 100 percent. Of course, the high real rates of interest ultimataly breed their own instability, since debts are being rolled over at these rates and thus must eventually get entirely out of line with the tax base or the return from real capital. What looks like a holding action, therefore, is in the end yet another debt crisis, this one domestic, to be resolved either by repudiation or by inflation.

The first problem, then, is the inflation cost, or real interest cost, of securing the budget revenue for debt service.

\section{THE FOREIGN EXCHANGE PROBLEM}

The second problem is to translate the increased budget revenue into earnings of foreign exchange. When inflation is used to finance the government, the process is direct: the government issues money to buy foreign exchange, forcing the rate to whatever level is necessary to buy the needed amounts. Private speculation goes in the same direction, and hence real depreciation and high or even accelerating inflation are the 
rule. If taxation or expenditure cuts are used, the adjustment is more complicated. To maintain full employment, relative prices now must change. In terms of the model set forth at the outset of this paper, the real price of home goods must decline, releasing resources to the traded goods sector even as the public sector is cutting spending.

Real depreciation means, in practice, that the real wage must fall in terms of tradables. The only way a country can gain access to additional foreign exchange is to reduce its dollar costs. The extent of the required reduction depends on two factors. The first is the domestic response of employment in the traded goods sector to the real wage. The more responsive employment is, the smaller the real wage cut. The other is the elasticity of demand for the country's output. The size of the foreign trade sector certainly is a consideration here. The larger the trade sector, the easier it becomes, other things being equal, to generate foreign exchange worth an extra percent of GDP.

With perfectly elastic demand, the problem is entirely classical. If demand is less than perfectly elastic, however, it becomes necessary to put the country's resources on sale, raising the possibility that quite substantial real wage cuts and cuts in the standard of living will be required to achieve a given trade surplus.

The importance of the size of the foreign trade sector is evident in a comparison of Brazil and Korea. Generating a given increase in the trade surplus is much easier for Korea, because its export sector accounts for a relatively large share of GNP. Other things being equal, Brazil would need a depreciation three to five times as large as that of Korea to have the same payoff in terms of net foreign exchange revenues. That, of course, has an immediate impact on inflation as well as on political considerations, such as the redistribution of income between different sectors.

In Korea income distribution is remarkably equal, social services are advanced. Real depreciation is largely uncontroversial, because it does not significantly redistribute income between different groups. In Brazil, where income distribution is highly unequal, real depreciation is a politically divisive real wage issue. Furthermore, in Korea real depreciation is practically a growth machine, since it applies to the large trade sector and thus a very large share of GNP. In Brazil, by contrast, where the trade sector is small, depreciation is seen primarily as a disruptive cost rather than an important policy for growth. Moreover, because 
income distribution is so unequal in Brazil, indexation arrangements are essential to avoid political confrontation, and that in turn means real depreciation is largely impossible.

The difference in structure explains why Korea can use depreciation to achieve external balance correction with little inflation and a large and favorable impact on growth. It also explains why Brazil avoids depreciation, as being inflationary and disruptive, and chooses, instead, trade restriction and recession.

\section{SYSTEMWIDE PROBLEMS}

The transfer problem has a third dimension. Actual debt service, if there are no assets to be liquidated, can be effected only in kind, that is, by a trade surplus. But that raises two separate difficulties. The first is that when many LDCs try, at the same time, to service their debts by trade surpluses, they are pursuing jointly a real depreciation policy that worsens their terms of trade. This secondary burden of the transfer is unquestionably part of the LDC terms-of-trade deterioration.

The second issue, already raised above, is market access. The creditor countries, concerned about increased imports, respond to the increased cost competitiveness (due to devaluation) of the LDCs with trade restrictions. But if debt service is to continue, LDCs will have to gain yet more in competitiveness to overcome the new restrictions. Gaining competitiveness, of course, implies reduced real wages and a reduced standard of living.

\section{DEBT SERVICE FATIGUE}

Given the intense difficulties involved in generating debt service, it is reasonable to ask why LDCs service their debts rather than declaring default. One reason is clearly that the system is so well managed that liquidity problems that would make nonpayment inevitable do not occur. Why, having a choice, do the LDCs continue to pay? In the past, they acted on the belief that failure to service debts would be extremely expensive in foreign policy terms: assets would be seized, trade would be disrupted, and the debtor countries might effectively become siege economies. At present, an even more fundamental concern is that default on the external debt would immediately translate into even larger 
domestic instability. Capital would try to leave through any available channel. Inflation control would disappear and, with it, political stability. Moreover, from questioning external debts, it is a short step to asking questions about domestic debts and, more generally, income distribution. The politics are much too precarious for a government to open that box. The most striking confirmation of this turn of thinking comes from President Alfonsin of Argentina. Only a year ago he claimed that his country's foreign debt could not be serviced with the blood and tears of his people. In August of this year, he told the assembled national financial community that the international debt would be serviced with dignity.

The reduction of LDC debt-export ratios that is under way is said to be in the interest of "the international system," as if the community at large had an interest. Clearly, creditor banks do, but that is where things stop. Industrial countries as a group have little interest in paying for the premature interest receipt with increased unemployment and foreign policy confrontation. In the debtor countries the accelerated debt service is altogether perverse. It means not only a cut in per capita consumption but also a deterioration of trend growth potential, with saving financing debt service rather than investment. There is a growing gap between productive employment, as opposed to government jobs, and the rapidly growing labor force.

Few are willing to argue that the present policy of reducing debtexport ratios is strictly temporary, very soon to be reversed by renewed resource transfers from the industrial countries to LDCs. That, of course, raises the question of whether an ongoing policy of forced debt service is not outright counterproductive. On a cash-flow basis the debt problem is more or less under control, but debt service fatigue is building up even in developing countries where the external balance is not the principal issue. Rightly, these countries blame their poor macroeconomic performance on the difficulty of servicing debt at short notice. The banks cannot be expected to make the first gesture in adjusting debt service, but surely it is not sensible to make it a matter of national interest that LDCs should service debts at a pace congenial to the international financial system, as an open-ended commitment without targets and without apparent benefit to the debtor LDCs. Carlos Diaz-Alejandro reminds us of what happened last time:

Led by able technocrats, Argentine economic policy adjusted; the country managed to maintain punctual servicing of the national external debt and provide 
foreign exchange for profit remittances abroad. Argentine growth and industrialization even managed to pick up, and by the late 1930s all seemed reasonably well. The nationalist-populist coup of June 1943, however, was able to revive memories of wounded national pride with notable domestic political success and with disturbing consequences for the international system. ${ }^{26}$

\section{APPENDIX}

\section{Welfare Analysis in a Two-Period Setting}

THIS APPENDIX spells out the welfare analysis of the undistorted economy in a simple two-period setting. The procedure follows the standard Meade-Fleming welfare calculus using a utility function, the assumption of maximization under perfect competition by households and firms, and the intertemporal budget constraint. Households maximize a utility function:

$$
V=U\left(C_{m}, C_{m^{*}}, C_{c}, C_{n}\right)+R U\left(C_{m}^{t+1}, C_{m^{*}}^{t+1}, C_{c}^{t+1}, C_{n}^{t+1}\right),
$$

where $R$ is the discount factor determined by the rate of time preference. The budget constraint states that two-period expenditures valued at world prices and world interest rates must equal the present value of income. Expenditures include investment:

$$
\sum p_{i}\left(D_{i}-Q_{i}\right)+b+R^{*} \sum p_{i}^{t+1}\left(D_{i}^{t+1}-Q_{i}^{t+1}\right)=0,
$$

or, using the definition of imports and exports:

$$
\sum p_{i} M_{i}-X+R^{*}\left(\sum p_{i}^{t+1} M_{i}^{t+1}-X^{t+1}\right)+b=0,
$$

where commodity $j$ is chosen as numeraire. The demand levels are $D_{i}=C_{i}+I_{i}$ and $D_{i}^{t+1}=C_{i}^{t+1}$. The term $b=B_{0} / P_{j}$ denotes the real value of the initial debt, measured in terms of commodity $j ; M_{i}$ denotes the level of imports and $X$, the level of exports. The term $R^{*}$ is the international real discount factor, with the real interest rate measured in terms of commodity $j$ :

$$
R^{*}=\left(\frac{P_{j}^{t+1}}{P_{j}}\right) \frac{1}{\left(1+i^{*}\right)}=\frac{1}{\left(1+r_{j}\right)},
$$

26. Diaz-Alejandro, "Latin American Debt," p. 389. 
Where $r_{j}$ is the implicit real interest rate.

The marginal welfare effect of disturbances is calculated as the first order approximation of equation 13. Differentiating equation 13 totally and using the budget constraint as well as the first order conditions that show equalization of relative marginal utilities or products to relative prices, I obtain:

$$
\frac{\mathrm{d} V}{U_{j}}=\Delta W=-\mathrm{d} b-\left(\sum M_{i} \mathrm{~d} p_{i}+R^{*} \sum M_{i}^{t+1} \mathrm{~d} p_{i}^{t+1}\right)+\frac{K \mathrm{~d} R^{*}}{R^{*}}
$$

where $K$ denotes initial debt plus the first period trade deficit, that is $K=b+\sum p_{i} M_{i}-X$. The first term measures the welfare benefit of a reduction in the real value of debt through write-offs. The second term represents the welfare reduction that arises from terms-of-trade changes. The terms-of-trade loss is equal to the income effect of a price change and is measured by the level of imports times the increase in the real price of imports. Of course, for a good of which the country is a net exporter, imports are negative and hence a real price increase represents a welfare gain. The last term finally measures the welfare cost of a rise in the real interest rate. It is equal to first period debt plus borrowing times the rise in the real rate of interest.

Equation 16 identifies only three external influences on home welfare: reductions in external debt, terms-of-trade changes, and real interest changes. Foreign activity, in the absence of domestic distortions or borrowing constraints, has no direct impact on welfare except through any induced changes in the home country's equilibrium terms of trade. Of course, a foreign shock in demand will typically affect at the same time commodity prices and interest rates so that there would be additional effects to be taken into account.

In the presence of credit rationing the derivation follows that above except that now maximization takes place subject to the additional constraint that the current account deficit in the first period be less than or equal to a given available credit line $J$ :

$$
\Sigma M_{i} p_{i}-X \leqslant J .
$$

If the credit constraint is effective, the shadow discount factor $R^{\prime}$ falls short of the world discount factor $R^{*}$. The extent of credit rationing is indicated by $0<R^{\prime} / R^{*}=\gamma<1$. Credit rationing modifies equation 16 to: 
(16a) $\Delta W=-\Sigma M_{i} \mathrm{~d} p_{i}-R^{*}(1-\gamma) \Sigma M_{i}^{t+1} \mathrm{~d} p_{i}^{t+1}$

$$
+(1-\gamma) J\left(\frac{\mathrm{d} R^{*}}{R^{*}}\right)+\gamma \mathrm{d} J .
$$

The presence of credit rationing is reflected in the valuation of future terms-of-trade improvements and of discount rate shocks. It is most apparent in the extra term $\gamma \mathrm{d} J$, which is the welfare gain of extra credit. 


\section{Comments and Discussion}

William H. Branson: This paper by Rudiger Dornbusch is, as his usually are, full of interesting and useful facts, tables, regressions, and suggestive hypotheses, all of which make it at least good reading. In his analysis of performance links, Dornbusch focuses on three channels of influencecommodity prices, real interest rates, and quantity effects on exportsrunning from OECD macroeconomics to the condition of the LDC debtors. He concludes that OECD expansion or contraction has conflicting effects on LDC debtors through these channels and that it is necessary to specify the exogenous source of OECD expansion to reach a clear conclusion about what those effects might be. I agree. For example, an investment-led expansion in the OECD would raise real interest rates and reduce lending to the LDCs, and increase the demand for their exports. Since the expansion of international capital markets in the 1970s, we can no longer rely on simple Keynesian export multipliers to analyze transmission from the OECD to the LDCs.

In general, I agree with the analysis and the somewhat ambiguous conclusions of the paper. But several issues require clarification, and others elicit minor disagreement and questions about approach. I raise these issues more or less in the order in which they appear in the paper.

One focal point of the paper is how differences in structure or policy among LDCs (or groups of LDCs) account for their differing responses to external disturbances. To sort out these differences among LDCs, three hypotheses are offered at the beginning of the paper. The first, Dornbusch's favorite, is that countries differ in trade structure or initial indebtedness. The second is that they differ in domestic policies. The third is that they have "a differential ability to adapt to external shocks." These are indeed important points, but their status as competing hypoth- 
eses is not clear. Cannot the third problem be due to the first, for example? Differential ability to adjust might be due to structural differences. By now the literature on policy response is well developed enough that we might consider differences in domestic policy to be part of the differential structure of the economies involved. Thus the paper begins with an uncharacteristic ambiguity on the separateness of the hypotheses to be considered, contributing to the somewhat discursive tone maintained throughout. One point on language might be worth noting here, too. The implicit opposite of "moderation in budget deficits and tradeoriented policies" is given as "waste and inefficiency." We might want to consider more reasonable-sounding alternatives.

The first substantive section of the paper presents a very clear and elegant framework model for analyzing terms-of-trade effects on debtor LDCs of various shocks to the system. The model is later used to introduce the importance of structural differences between countries, especially in trade patterns. I think one additional type of trade structure could have been brought into the model at this point. Many developing countries, mainly in Africa, still export one or two tree or mineral crops with inelastic export supply. They also import capital goods and intermediate inputs with inelastic import demand. This pattern of trade substantially reduces trade elasticity in these countries and calls into question the effectiveness of devaluation as a policy for maintaining or restoring trade balance. I emphasized this point in a 1983 article referred to by Dornbusch, ${ }^{1}$ and I would be interested to see how this kind of structural difference would fit into the framework model. Perhaps the $N N$ curve in figure 1 would steepen and the $M M$ curve would flatten.

The importance of differences in openness, emphasized in the paper by Jeffrey Sachs, also in this issue, is apparent in Dornbusch's table 4. Latin America has a much higher debt-export ratio relative to its debtGDP ratio than does Africa or Asia, mainly because of the lower exportGDP ratio in Latin America. The more closed economies in Latin America have less relative capacity for debt service than the more open Asian ones do, and so run into crisis conditions sooner. The African LDCs have a low interest-export ratio, compared to their debt-export ratio. A high proportion of African borrowing is from international institutions at subsidized rates, while Latin American and Asian borrow-

1. William Branson, "Economic Structure and Policy for External Balance," in A. W. Hooke, ed., Exchange Rate Regimes and Policy Interdependence (International Monetary Fund, 1983), pp. 39-74. 
ing is from banks. The analysis of the importance of trade structure provides a useful link between the Dornbusch and Sachs papers.

A second point on the framework model is that the three channels of influence are not themselves exogenous events. In general, any macroeconomic disturbance in the OECD will have effects on the LDCs through all three channels. This is shown in the offset case presented in Dornbusch's table 2, which takes off from the Reagan quotation. There, trade effects and debt effects are largely offsetting. The point is important and substantive, but it also calls into question the usefulness of the categorization of transmission channels mentioned earlier. To use the framework model, we must first translate any given exogenous world disturbance into effects on the LDC involved via terms of trade, debt service, and export volume, and then aggregate these into a net effect, as in table 2.

In applying the model Dornbusch rightly emphasizes that welfare effects generally come from exogenous changes in relative prices at initial quantities. These are the usual welfare effects of public finance theory. The endogenous adjustment of volume in a fully employed economy requires that resources be moved from alternative uses toward, for example, the traded goods sector. This is all summarized neatly in the welfare measure of equation 3.

Exceptions, in which export volume effects should also be counted as welfare gains, generally come in cases where an initial disequilibrium already exists when the disturbance occurs. In the case of preexisting wage rigidity and unemployment, for example, the official price of foreign exchange might be less than the shadow price because resources are free to move to the traded goods sector. In such a case export volume effects could justifiably be included in the welfare calculation for a policy to counter the recession due to an external shock. Of course, this may be policy that is only second-best to the preferred one of removing the distortion in foreign exchange pricing in the first place.

This is the line that Dornbusch, correctly, takes in the theoretical analysis presented in the first part of the paper. It is a useful alternative to the usual practice of including hard-earned expansion of export volume as positive in the welfare calculation. But after the good start, Dornbusch backslides. Export volume effects play a central role in his analysis of the effects of an OECD expansion and are featured in his discussion of policy alternatives. Too bad!

Inow turn to the third section of the paper, on quantifying the linkages. 
The connection between LDC and OECD growth is summarized in table 6 . The regressions show a significantly positive but unstable elasticity of response of LDC to OECD growth. The result is suspect for two reasons. First, the table and surrounding text suggest that the LDC growth data do not adjust for changes in debt service as interest rates react to OECD growth. The data of table 2 show that this can be an important adjustment. This raises the question of whether the table 6 results would stand up if this adjustment were made to both LDC and OECD growth. Second, the results could change if the regression period were broken into the subperiods $1960-73$ and 1973-84. The data of table 10 provide an implicit comparison of OECD growth in GDP and LDC export volume growth for the subperiods 1960-70 and 1970-83. OECD growth fell from the earlier to the later period, while LDC export volume increased. Thus the positive relation between GDP growth rates in table 6 might weaken substantively if the sample period were divided.

The analysis of movements in real commodity prices leaves several loose ends, although the model of equations 5-8 is exemplary in its clarity on the need to define real commodity prices in terms of a currency basket. Figure 5 and table 8 present commodity price indexes deflated by the industrial countries' average export unit value. But in table 9 , the regressions for determinants of real commodity prices use indexes deflated by the U.S. GNP deflator. These overemphasize the role of the dollar in a period of dollar appreciation vis-à-vis the EMS and the yen. The point that dollar appreciation should lower real commodity prices in terms of the dollar, but raise them in terms of the EMS, is made in the text but is obscured in table 9 . This problem reappears in the policy discussion that follows, where the focus is on the real price of commodities in terms of the dollar.

A final point on quantification is raised by the interpretation of the table 11 regressions for export volume growth. These include a competitiveness variable measured by changes in relative prices. The coefficient of this variable is significantly negative, leading Dornbusch to comment that "the significant response of export volume to competitiveness of course points to adjustment programs that involve real depreciation as an important element.' In fact, the table 11 results suggest that this may be true for LDC manufacturing exporters, but not for the rest of the LDCs. The first two equations of the table are for all LDCs, and the competitiveness coefficient is around -0.5 . The second two equations 
are for manufacturing exporters, and the coefficient is about -1.25 . The first coefficient weights manufacturers and nonmanufacturers into an overall average. If manufacturing exporters have a weight of 0.4 or more in total exports of LDCs, the coefficients in table 11 would be consistent with a zero or negative elasticity of the nonmanufacturers' exports to changes in competitiveness. ${ }^{2}$ Thus Dornbusch's results in table 11 implicitly support the hypothesis that nonmanufacturing exporters such as the African LDCs have much lower elasticity than the manufactures exporters. I argued this position in the 1983 article cited by Dornbusch.

Dornbusch's discussion of OECD policy mixes draws on the previous results to note the ambiguity of the effect of OECD growth on the LDC borrowers unless the source of this growth is specified. The need for a shift in the mix of monetary and fiscal policy in the OECD, with fiscal tightening in the United States and ease in the rest of the OECD, has been, and still is, advocated by Dornbusch as forwarding the interest of both the industrial countries and the LDCs. I agree.

William R. Cline: Rudiger Dornbusch's paper deftly summarizes the analytical framework for the influence of OECD macroeconomic performance on the problem of LDC debt, and I broadly agree with his approach. My comments will focus on points of disagreement and on some specifics.

The empirical estimation of net windfall changes from terms of trade, LIBOR, and inflation in 1984 in table 2 is seriously misleading. Because Dornbusch obtains a long-term discount factor from an extremely shortterm price trend-three months-his measure is subject to volatile swings. Compounding the problem, the price concept is LDC export unit value, which is much more unstable than the overall price concept for opportunity costs of both exports and imports. Specifically, for AprilOctober 1984, Dornbusch's three-month forward period, export prices fell 2.2 percent relative to January-July 1984. Dornbusch annualized this trend to an 8.8 percent decline, compared with a decline of only 0.6

2. Let $\epsilon$ represent elasticity of export volume with respect to competitiveness, with subscripts $t$ for total, $m$ for manufacturers and $n$ for nonmanufacturers. Let $\alpha$ be the share of nonmanufacturers in total exports. Then the estimated elasticity coefficients are related by:

$$
\epsilon_{t}=\alpha \epsilon_{n}+(1-\alpha) \epsilon_{m},
$$

with table 11 giving $\epsilon_{t}=-0.5$ and $\epsilon_{m}=-1.25$. Then if $\alpha=0.6, \epsilon_{n}=0$. 
percent in 1983 on a comparable basis, giving a reduction in inflation that far exceeds the 12 percent reduction in LIBOR and causes a windfall $\$ 39$ billion loss from the discount factor. If, instead, a slightly longer time period is used for the price trend-year-on-year increases for 1984 and 1983 - and the average of industrial country and LDC export unit values is used as the price concept, application of Dornbusch's equation for the real discount factor, $R^{*}$, gives 0.892 in 1984 and 0.841 in 1983, for an improvement of 0.051 instead of a deterioration of $0.076 .^{1}$ The principal difference is that measured inflation increases from -6.6 percent in 1983 to -1.9 percent in 1984 , in contrast to a decrease from 0 percent in 1983 to -8.8 percent in 1984 in the Dornbusch three-month windows as annualized. On this basis, the windfall effect from a change in the real discount factor is a gain of $\$ 31.2$ billion instead of a loss of $\$ 38.8$ billion, and the total net windfall effect in Dornbusch's table 2 becomes a gain of $\$ 70.4$ billion instead of only $\$ 0.4$ billion. President Reagan is right (and conservative) even on windfall effects, on this basis. But the broader point is that the calculation of long-term present values of real debt based on very short-term variations in price, especially LDC export unit values, can give rise to nonsense results because of wide fluctuations.

Dornbusch is, of course, correct to remind us that nominal export values should not be compared with these windfall effects, because resources are required to increase export value. But his own framework subsequently allows for welfare gains from trade volume increase in the presence of idle domestic capacity (which existed) and a high shadow price of foreign exchange (also present). The volume increase in nonoil LDC exports in 1984 amounted to $\$ 24.8$ billion at 1983 prices. Applying a shadow price premium of 30 percent, the expansion of export volume generated a welfare gain of $\$ 7.4$ billion. Once again President Reagan was right; he merely omitted the following sentence fragment in his draft speech: "After taking account of the shadow price premium on foreign exchange. ..."

The model of welfare effects proposed by Dornbusch is useful. It would be helpful to develop its implications for the current debate on resource transfers. That debate typically ignores the fact that outward resource transfer does provide a positive welfare effect in the reduction of the terminal debt on the country's balance sheet; Dornbusch's

1. International Monetary Fund, International Financial Statistics, vol. 38 (September 1985), pp. 72-73, 480. 
equation explicitly includes terminal debt with a negative sign. Similarly, exploration of the different conditions under which export volume expansion has positive welfare effects-low resource utilization, high foreign exchange shadow price-or negative welfare effects, as assumed in the standard critique of outward transfer of resources, would be helpful.

The analysis of real commodity price finds a statistical fact without a theory: the real price is inversely related to the strength of the dollar. At the outset the discussion accurately states the intuitive relationship: dollar strength should affect only the nominal commodity price, not its real price relative to manufactures. In particular, the nominal dollar price of all traded goods, manufactures or commodities, should be expected to move negatively with the strength of the dollar, by the proportion: unity minus U.S. share in world trade. Otherwise, a change in the exchange rate between the dollar and other currencies would cause a change in the real resources commanded globally by a pound of coffee, for example. ${ }^{2}$

If the Dornbusch finding is robust, it is important for the debt problem, because it means that as the dollar declines from its overvalued levels of 1982-84, there will be twofold relief. Nominal dollar debt will be easier to carry as nominal dollar export values rise from dollar depreciation expected in theory, and as the dollar value of a given real trade surplus, which most major debtors currently have achieved, increases. In addition, the export base will rise still further for commodity exporters from a gain in real price (the unexplained empirical observation). A caveat is in order, however, considering the continued erosion of dollar prices of commodities through the third quarter of 1985 despite the dollar's significant decline from its February high.

Ronald McKinnon has suggested one reason for a negative correlation

2. I prefer the following formulation: percentage change in dollar price of traded goods equals average international domestic inflation plus 0.8 times percentage depreciation of the effective exchange rate of the dollar, with 0.2 as an approximate parameter for the share of the United States in world trade. This equation tracks the data relatively well; in 1976-78, cumulative consumer price inflation in industrial countries averaged 16.2 percent, the dollar declined by 9 percent, and world trade prices in dollars (unit value of industrial country exports) rose by 22 percent. In $1980-84$, cumulative consumer price inflation averaged 30 percent, but traded goods prices in dollars actually declined by 12.6 percent because of a rise in the dollar of 43.7 percent. International Financial Statistics, various issues. 
of real commodity prices with dollar strength (by communication). Because of the important role of the dollar in the international money supply, a weak dollar tends to coincide with global inflation-expansion, while a strong dollar is usually associated with more deflationarycontractionary global macroeconomic conditions. Thus, the influence of global business activity may be picked up by dollar strength, contributing to real commodity price change. Although Dornbusch's equations already include activity directly, there may be an additional expectational dimension for activity reflected by dollar strength.

If the real commodity price link to the dollar is reliable, Dornbusch's distinction between commodity importers such as Korea and exporters such as Brazil is useful in differentiating macroeconomic impact on the debt problem. Perhaps an even more important distinction Dornbusch omits is that between oil exporters and oil importers. Because past prices have been administered and underlying trends are toward weakness, oil is the one major commodity in which dollar prices are unlikely to rise in the medium term in response to a decline in the dollar's strength. For oil exporting countries, dollar depreciation tends to aggravate the debt burden, by raising the dollar price of imports without compensation in oil prices. A final note on the commodity estimates is that they show a surprisingly low influence of interest rates; one would have expected that high interest rates had played a substantial role in the weakness of prices for some commodities, such as copper, through the reduction in demand for inventories.

The new empirical estimates of the export volume and revenue elasticities of LDC exports with respect to OECD growth are a useful addition to the literature. They tend to confirm relatively high responsiveness, and thus to reinforce the prevailing view of the importance of sustained OECD growth for resolution of the debt problem. Whether the cyclical export volume elasticity is 2 or 3 -and whether it sharply exceeds the secular elasticity of about 2-is probably less important for the future than it was in the period 1982-84, when the OECD growth rate rose by a highly unusual 5 percentage points. Dornbusch might highlight more than he does the other result in these equations: the country's real exchange rate makes a significant difference to export earnings, especially for exporters of manufactures. This result provides additional evidence for trade elasticity optimism and encouragement that debtor countries can affect their situation by their own policy measures. 
On the implications for macroeconomic policy in industrial countries, I would agree completely that the ideal scenario is one in which interest rate declines prompt not only OECD growth but also a declining dollar. At one point, however, Dornbusch seems to see a current paralysis in the options, because he fears the inflationary impact of depreciation. Surely that impact will be greater and the real distortions of the allocation of resources between tradables and nontradables more severe the longer the correction of the dollar is postponed-and continuation of the current situation may not be a real option. The scenario finally preferred by Dornbusch-correction of the fiscal deficit "over the next few years," transitory European fiscal expansion, and a soft landing for the dollaris plausible, but a more immediate fiscal correction, combined with compensating monetary expansion, would be preferable; and a smooth but more rapid correction of the dollar within, say, two to three years would surely be preferable to an extremely slow correction.

Dornbusch's equation 10 is the right one for analyzing the conditions for improvement in the debt problem. ${ }^{3}$ Table 13 is misleading about the performance using the criterion of interest rate compared with export growth, however. If the latter period were divided into 1980-82 and 1983-84, the results would appear far more favorable, as nominal interest rates declined while export growth recovered in the latter period. ${ }^{4}$ Dornbusch is right to conclude that nominal export growth in the range of 10 to 15 percent may be expected. Over the next four years I would specify this growth as follows: 6 percent volume (elasticity of 2 applied to OECD growth of 3 percent), plus 5 percent for world inflation, plus perhaps 5 percent annually for dollar depreciation $(0.8$ times dollar depreciation), for annual nominal growth of 15-16 percent.

Dornbusch's conclusion that OECD developments will do little to help debtors, and that LDCs must resolve the debt problem on their own, may be somewhat misleading if interpreted to mean that they will

3. For a similar development of this equation and its application to the examination of combinations of OECD growth and LIBOR at which recovery from the debt problem continues, see William R. Cline, "International Debt: Analysis, Experience, and Prospects," Journal of Development Planning, no. 16 (1985), pp. 25-55.

4. For 1985 the data in table 13 are misleading. In October the IMF forecast that 1985 export value in dollars would decline by 0.2 percent for nonoil LDCs, instead of 9 percent as indicated in the table. See International Monetary Fund, World Economic Outlook (October 1985), p. 66. Exports in 1985 were expected to rise by 4 percent in volume, however, suggesting that once the effects of the reversal of sharp dollar appreciation in early 1985 are felt, dollar export earnings will begin to rise again as well. 
have to accept still lower growth in the future and carry out much more severe real devaluations than they have already experienced since 1982. On the contrary, the debt equation would suggest that they can make rapid progress toward creditworthiness merely by maintaining their current relatively high trade surpluses. With LIBOR plus spread at perhaps 11 percent, export growth at 15 percent, the trade surplus at 27 percent of exports, and the debt-export ratio at 3, equation 10 gives a decline of the debt-export ratio to 2, a threshold often associated with creditworthiness, within three years, a decline at 13 percent annually. And experience in Brazil in 1985 suggests that continued trade surpluses are feasible even in the face of domestic recovery in the debtor countryif real appreciation of the exchange rate is avoided.

Dornbusch's analysis of inflation is suggestive but basically misleading to the extent that it might imply that the problem of domestic inflation may be attributed to the external debt crisis. Venezuela's inflation is in the range of 10 percent while Argentina's passed 1000 percent, but both countries had to face comparable shocks in import cutbacks in dealing with the debt problem. The fiscal squeeze from borrowing at home what can no longer be borrowed abroad depends on the extent to which real interest rates on borrowing from the public at home exceed international rates. Despite the spectacular real rates cited by Dornbusch (which are too high even for corporate borrowers who sometimes pay 30 percent; savers are lucky to receive 10 percent or even positive real rates at all), the domestic rates to the government are not generally far above international rates. As for real wages in the adjustment process, they need not decline if the share of nontradables in the consumption basket is sufficient, because real wages must rise in terms of nontradables; otherwise the profit signal to switch resources to tradables is missing.

Dornbusch is of course right to stress the need to avoid protection, although the current risk seems to be more that the debtor countries will be sideswiped by a general protectionist response to the overvalued dollar, with the main focus on Japan, rather than singled out for protection, partly because of adverse effects on Brazil and other debtor countries. Dornbusch is also correct to highlight the emerging problem that banks may be too ambitious in their timetable for disengagement from Latin America, causing excessive contraction of external deficits. 


\section{General Discussion}

Several discussants of Rudiger Dornbusch's paper commented on table 2, which contrasts cash-flow calculations with welfare calculations concerning the effects of changes in the international economic environment over the 1983-84 period on the LDCs. In Dornbusch's analysis of export revenues, only changes due to changes in the terms of trade holding export volume constant improve welfare, since effort and resources are required to produce additional exports. But Lawrence Krause noted that the Asian economies value increased export volume because it helps them to realize economies of scale that they cannot realize within their domestic economies. Paul Krugman was uneasy about Dornbusch's method of calculating the real interest rate in his welfare analysis. Krugman pointed to figure 8, which shows the Dornbusch-style real interest rate for nonoil LDCs swinging between +47 percent and -34 percent over the 1973-84 period, and implies an increase in the real rate of interest between 1983 and 1984 on the order of 35 percentage points. He questioned the relevance of a measure that could exhibit so much short-term volatility. If, for example, there were a large one-time increase in LDC export prices, the Dornbusch welfare calculation would show a large decrease in the real interest rate, followed the next year by a return to the original real interest rate. The LDCs' implied debt servicing costs would be lower in the year prices increased than in any subsequent year, so that looking at the figures for the first year in isolation would be very misleading. Both Krugman and John Williamson suggested modifying Dornbusch's real interest rate calculations to take into account both current changes in relative exchange rates and expectations concerning future changes, though neither was able to suggest specifically how this might be done.

Williamson argued that in 1980 there was no reason to consider the volume of LDC borrowing excessive, but he suggested that there should have been concern over so much of the borrowing taking the form of floating rate loans, which impose all of the interest rate risk on the borrower. In Williamson's view, arrangements under which lenders and borrowers shared that risk would have been preferable and should be sought in the future. Richard Cooper questioned whether such an arrangement would have been feasible in 1980 . He noted that the OPEC 
countries were a major source of funds for lending in 1979 and 1980 and that they had been quite unwilling to lend on other than a short-term basis. Williamson replied that the fact that the OPEC countries were the immediate source of funds for many of the LDC loans was not particularly relevant. The total world capital market is many times the size of all OPEC funds combined, he reasoned, so that it should have been possible to draw upon other sources of world savings for the LDC loans.

Several comments were directed towards the quantitative analysis of linkages between the OECD economies and the LDC economies presented in the third section of the paper. One puzzle in those results is the larger-than-expected effect of dollar appreciation on commodity prices in the table 9 models. Robert Lawrence suggested that this large effect might reflect problems with the Economist commodity price index. He pointed to table 8, where data on both the Economist and the IMF index of commodity prices are presented; the two move quite differently, and the Economist index appears to be more volatile than the IMF index. The weighting underlying the Economist index is a bit odd, since it gives a large weight to just a few commodities, such as copper. Williamson noted the implication of table 11 that the volume of nonmanufactured exports responds very little to shifts in exchange rates and cautioned against interpreting this as evidence that countries relying on nonmanufactured exports need not worry about maintaining competitive exchange rates. Instead, he interpreted the low elasticity as evidence that creating new trade movements can take quite a long time. Finally, Lawrence advocated looking at reduced-form models of the effect of exogenous factors on the terms of trade, rather than only estimating the intermediate linkages in sequence. 